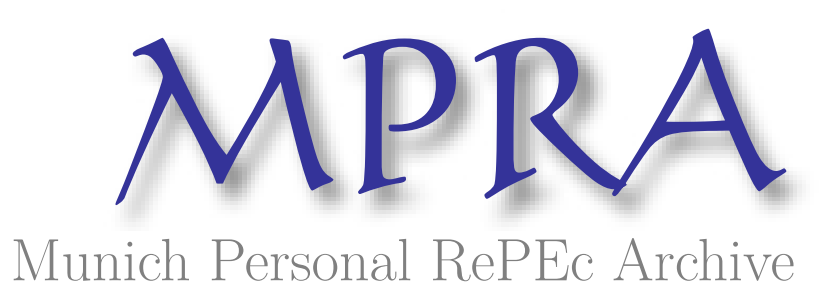

\title{
Three's company: Wall Street, Capitol Hill, and K Street
}

Igan, Deniz and Mishra, Prachi

November 2011

Online at https://mpra.ub.uni-muenchen.de/44220/

MPRA Paper No. 44220, posted 05 Feb 2013 20:22 UTC 


\title{
Three's Company: \\ Wall Street, Capitol Hill, and K Street ${ }^{\dagger}$
}

August 2012

Deniz Igan and Prachi Mishra

\begin{abstract}
This paper explores the link between the political influence of the financial industry and financial regulation in the run-up to the global financial crisis. We construct a detailed database documenting the lobbying activities, campaign contributions, and political connections of the financial industry from 1999 to 2006 in the United States. We find evidence that spending on lobbying by the financial industry and network connections between lobbyists and the legislators were positively linked to the probability of a legislator changing positions in favor of deregulation. The evidence also suggests that hiring connected lobbyists who had worked for legislators in the past enhanced this link.
\end{abstract}

JEL Classification Numbers: G21, P16

Keywords: Lobbying, PAC, Financial Regulation

\footnotetext{
${ }^{\dagger}$ We would like to thank Stijn Claessens, Matthew Jackson, Atif Mian, Marcelo Pinheiro, Amir Sufi, Francesco Trebbi, and participants at the ASSA Annual Meetings in Denver, CIRANO Networks Workshop in Montreal, ISB Summer Research Conference in Hyderabad, London School of Economics, University of Arkansas, George Mason University, World Bank, and IMF RES Brown Bag and MFU Internal seminars for useful discussions and suggestions. We are grateful to Daniel Schuman and Ryan Sibley of the Sunlight Foundation for their help in clarifying the intricacies of the legislative process and reporting of politically targeted activities. Jiawei Chen, Lisa Kolovich, Roxana Mihet, and Yorbol Yakhshilikov provided outstanding research assistance. All remaining errors are our own. Corresponding author: Deniz Igan, Email: digan@alumni.princeton.edu. DISCLAIMER: This paper is disseminated without any affiliation, and the views expressed in this paper are completely those of the authors and do not represent those of any institution with which the authors are otherwise affiliated.
} 


\title{
Three's Company:
}

\section{Wall Street, Capitol Hill, and K Street}

August 2012

\begin{abstract}
This paper explores the link between the political influence of the financial industry and financial regulation in the run-up to the global financial crisis. We construct a detailed database documenting the lobbying activities, campaign contributions, and political connections of the financial industry from 1999 to 2006 in the United States. We find strong evidence that spending on lobbying by the financial industry and network connections between lobbyists and the legislators were positively linked to the probability of a legislator changing positions in favor of deregulation. The evidence also suggests that hiring connected lobbyists who had worked for legislators in the past enhanced this link.
\end{abstract}

JEL Classification Numbers: G21, P16

Keywords: Lobbying, PAC, Financial Regulation 


\section{INTRODUCTION}

Regulatory failure, often argued to be linked to the political influence of the financial industry (Acemoglu, 2009; Calomiris, 2009; Johnson, 2009), has been alleged to be one of the key contributors to the recent global financial crisis (e.g., Obstfeld and Rogoff, 2010; Dagher and Fu, 2011). More generally, political economy factors may interfere with the process through which specific financial regulations are designed and implemented (e.g., Kroszner and Strahan, 1999; Rajan and Zingales, 2003; Benmelech and Moskowitz, 2010). While political influence can be an important factor shaping regulatory frameworks in any industry, ${ }^{1}$ it is particularly interesting to study the financial sector because it is one of the most heavily-regulated and the largest source of politically-targeted spending in the United States (Center for Responsive Politics, 2009).

Arguments for the link between financial regulation and political influence of the financial industry mostly rely on anecdotal evidence. ${ }^{2}$ Studying this link in a formal framework, however, is often constrained by availability of detailed information on politically targeted

\footnotetext{
${ }^{1}$ Political influence can also have an impact on economic and financial outcomes (e.g., Fisman, 2001, Cooper, Gulen and Ovtchinnikov, 2010).

${ }^{2}$ For instance, at the end of 2007, the Wall Street Journal reported that Ameriquest Mortgage and Countrywide Financial, two of the largest mortgage lenders in the nation, spent millions of dollars in political donations, campaign contributions, and lobbying activities from 2002 through 2006 (Simpson, 2007). The sought outcome, according to the article, was the defeat of anti-predatory lending legislation and fending off of similar laws. The Financial Times recounted a similar story based on a Center for Public Integrity study linking subprime originators to lobbying efforts to prevent tighter regulation of the mortgage market (Luce, 2009). In fact, banks continued to lobby intensively against tighter regulation and financial regulatory reform even as the industry struggled financially and suffered from negative publicity (Labaton, 2009).
} 
activities. The case of the United States provides an excellent opportunity to look into the issue in more detail for two reasons. First, it was the epicenter of a systemic financial crisis. Second, there is a wealth of publicly available information on political activities of the financial industry.

This paper studies the relationship between the political influence of the finance, insurance and real estate industry (FIRE) and financial regulation during 1999-2006 in the United States. In particular, we ask the following questions. Did politically targeted activities by FIRE have a link to the legislative outcomes of the bills on financial regulation? Were legislators' network connections with the financial industry and the lobbyists related to their decision to support certain proposals?

For our analysis, we construct a comprehensive dataset on the politically targeted activities of financial companies. Specifically, we gather (i) firm-level data on the lobbying expenditures targeted toward specific bills and on campaign contributions targeted to particular legislators; (ii) information on employment histories of the legislators and the lobbyists hired to work on these specific bills, to pin down the network connections between the legislators (Capitol Hill) and lobbyists (K Street) as well as the financial industry (Wall Street) ${ }^{3}$; (iii) detailed information on 47 bills related to financial regulation, including their provisions so that they can be grouped into broad categories based on their similarities.

Our empirical strategy is to exploit the cases in which legislators "switch" positions on a given legislation proposal. In other words, we use the variation in political spending by FIRE at the bill level and the variation in the position taken by the same legislator on the same issue in

\footnotetext{
${ }^{3}$ Capitol Hill is where the U.S. Congress offices are located, K Street is where many lobbyists have offices in Washington, DC, and Wall Street is where many financial companies have offices in New York.
} 
its different "reincarnations". Hence, the baseline specification looks at whether an individual legislator switches her support for a particular bill or not is linked to the lobbying expenditures by firms affected by the bill as revealed by their decision to lobby on that bill ('affected firms'), and to the network connections she shares with the lobbyists and the financial industry. The estimating equation controls for any unobserved time-varying legislator and bill characteristics. This strategy is similar to the one used in Stratmann (2002). The main findings emerging from our analysis are as follows.

First, lobbying expenditures by affected financial firms were significantly associated with whether or not the legislators switched their vote on the key bills that preceded the crisis: more intense lobbying on a bill was linked to better odds that a legislator would switch her stance in favor of deregulation in a subsequent reincarnation of a bill. This link is statistically and economically significant: a one standard deviation increase in spending on lobbying is associated with a 37 percentage-point increase in the probability of switching.

Second, network connections between legislators and lobbyists who worked on a specific bill have a significant positive association with switching from being against to being in support of deregulation: whether any of the lobbyists working on a bill also worked for a legislator in the past sways the stance on that bill in favor of deregulation. Having a connected lobbyist working on a bill is associated with an increase in the probability of switching by 2.5 percentage points.

Furthermore, network connections and certain legislator characteristics affect the strength of the relationship between lobbying and the probability of switching. Spending an extra dollar matters twice as much in switching a legislator's position if the lobbyist is connected to the legislator compared to the case where the lobbyist is unconnected. Lobbying has a 
stronger link to moving support towards deregulation if the legislator is more conservative and if the legislator worked in Wall Street.

Our paper contributes to an emerging body of work on the political economy of the recent financial crisis. Igan, Mishra, and Tressel (2011) look at the association between lobbying activities and risk taking by financial institutions in the run-up to the crisis. They show that lobbying lenders tended to engage more in risky lending practices between 2000 and 2006 and suffered worse outcomes during the crisis. This paper, in contrast, looks directly at the association of lobbying and campaign contributions to the outcomes of the legislative process governing financial regulation. By documenting the direct link between politically targeted activities and legislative outcomes, this study complements Igan, Mishra, and Tressel (2011), where one of the stories that could explain the link between lobbying and risk taking is that lobbying by the financial industry played a role in making the regulatory environment lax, which allowed the lenders to engage in riskier lending.

A couple of other papers look at the legislative outcomes in the context of the recent crisis. Mian, Sufi, and Trebbi (2010a) focus on the congressional voting behavior on two key pieces of legislation that shaped the regulatory response after the crisis. Mian, Sufi, and Trebbi (2010b) analyze voting patterns on six bills prior to the crisis. They find that constituent interests and special interests played a significant role in explaining voting patterns both prior to and after the crisis.

Our analysis adds to this growing literature in three important aspects. First, we address a broader question: rather than limiting the analysis to only a small set of bills on the mortgage market alone, we look at a large set of financial regulation proposals in the run-up to the crisis with far-reaching consequences for risk-taking in the financial system. Second, our 
measure of politically targeted expenditures is a more precise measure of special interests. Instead of using the aggregate contributions by the financial industry, we utilize firm-level information in order to establish a direct link between firms more likely to be affected by these proposals (revealed by their active lobbying agenda on these bills) and the legislators' position on these bills. Third, we bring in a dimension not explored in other studies, namely, the network connections between the legislators, lobbyists, and the financial industry.

To the best of our knowledge, our study is the first to provide evidence that voting on key bills on financial regulation was linked to the network connections between the financial industry, legislators, and lobbyists. These network connections are commonly tagged as the "revolving door". Bertrand, Bombardini and Trebbi (2011) document the importance of these connections in determining which issues lobbyists work on. Similarly, in a recent study, BlanesVidal, Draca, and Fons-Rosen (2011) show that lobbyists who have worked for legislators in the past generate more revenue. One possible explanation for this result is that connected lobbyists are more influential in securing the desired outcome for their clients than unconnected lobbyists are. Our results support this explanation as we show that lobbying spending by the financial industry through connected lobbyists is more strongly associated with the switch in a legislator's position toward deregulation.

Overall, our findings establish a robust link between voting patterns on financial regulation proposals and lobbying and network connections between legislators and the financial industry, either directly or through hiring of lobbyists. This link can be interpreted to support the notion that the political influence of the financial industry played a role in shaping the regulatory landscape in the run-up to the crisis. Going forward, financial regulation reforms currently under consideration may also be subject to such influence. 
The rest of the paper is organized as follows. Section II provides a brief account of the legislative process in the United States, the role of lobbying in this process, and the key legislative landmarks regarding financial regulation prior to the crisis. Section III describes the data and the methodology. Section IV presents the results of the empirical analysis. Section V concludes.

\section{BACKGROUND}

\section{A. Legislative Process}

The federal law-making process in the U.S., from the initial idea for a legislative proposal through its publication as a statute, is a not a simple or short one. ${ }^{4}$ The process is initiated by the introduction of a proposal in the form of a bill or resolution (which can be a joint, concurrent, or simple resolution) by a member/s of the House of Representatives or the Senate ('the sponsor' and the 'cosponsors'). Each bill must have a sponsor and may have zero or more co-sponsors. At this point, the proposals are assigned a legislative number by the clerk of the Congressional Record. ${ }^{5}$ These bills and resolutions are then referred to committees that deliberate, investigate, and, if necessary, revise them before they are accepted for general debate. Arguably, this is the

\footnotetext{
${ }^{4}$ For a complete explanation, see Document 110-49 of the U.S. House of Representatives available at http://thomas.loc.gov/home/lawsmade.toc.html.

${ }^{5}$ For instance, a bill introduced at the House of Representatives is designated by "H.R." followed by a number that it retains throughout all its parliamentary stages while bills introduced at the Senate is designated by "S." followed by its number. The term "companion bill" is used to describe a bill introduced in one House of Congress that is similar or identical to a bill introduced in the other House of Congress. The majority of proposals considered are introduced as bills rather than resolutions.
} 
most important phase of the process because, for the majority of bills and resolutions, this marks the end of the road. ${ }^{6}$ Should the committee decide to recommend a bill or resolution for approval, it usually prepares a comprehensive report that describes the purpose and scope of the bill and the reasons for its recommended approval, generally along with a section-by-section analysis setting forth precisely what each section is intended to accomplish. The original bill, if not 'dead' in a committee, often leaves the committee with several amendments. Once a bill or resolution is recommended by the committee(s) to which it was referred, it comes to the chamber that originated the bill for consideration and debate. At the end of the reading and discussion of the bill in its entirety, the originating chamber first votes on whatever amendments have been reported by the committee(s) and then immediately votes on the passage of the bill with the amendments it has adopted. ${ }^{7}$ If the bill passes, an engrossed copy, with all the amendments and in the exact same format that it was passed by the originating chamber, is sent to the other chamber of Congress. At this point, the measure ceases technically being a bill and becomes an

\footnotetext{
${ }^{6}$ Often legislation goes to subcommittees for consideration before moving to the full committee and sometimes it is the subcommittee that does all the work. Although it would be extremely interesting to study the committee decisions in addition to the other steps in the legislative process, we are not aware of any systematic record of these decisions.

${ }^{7}$ Note that the process followed on the chamber floor may differ since the Rules Committee may attach bill-specific rules that can limit debate, votes, amendments, etc. (see http://opencrs.com/document/98-853/2007-11-26/ and http://opencrs.com/document/98-426/2007-03-21/ for more details). Also, the voting at the originating chamber is the end of the process in some cases. In particular, simple and concurrent resolution are not functionally identical to bills in that they bounce to the other chamber and are passed by the President: simple resolutions are considered only by one chamber and concurrent resolutions are not sent to the President.
} 
'act' (although the popular term remains as a 'bill'). The act goes through similar steps in the second chamber: referral to committee(s), debate, and vote. The original engrossed bill, together with the engrossed amendments, if any, from the second chamber, is then returned to the originating chamber with a message stating the action taken by the second chamber. If there are any differences between the two versions, a 'conference' may be called to resolve any disagreements or competing versions bounce between each chamber until the disputes on legislative text is resolved (the so-called 'ping pong strategy'). Once an agreement on an identical form of the act is reached, a copy is presented to the President. A bill becomes law on the date of approval or passage over the President's veto, unless it expressly provides a different effective date.

The voting at either chamber may be done in one of three ways: the voice vote (where the chair asks first for all those in favor of the motion to indicate so verbally, and then ask second all those opposed to the motion to indicate so verbally), the division (where the members supporting and opposing the motion stand successively and are counted) and the recorded vote. By definition, only the recorded vote allows one to determine at a later date which members voted for and against a motion. As to be discussed later, this procedural factor limits the voting occasions we can formally analyze by forcing us to drop the bills for which a voice vote or unanimous consent were indicated as outcomes. In order to provide a more complete picture of the role of legislation governing financial regulation on the way up to the financial crisis, we also utilize information on sponsorship and co-sponsorship of a bill.

\section{B. Politically Targeted Activities}

Although lobbying is commonly recognized to be an influential political economy activity in many countries (Bertok, 2008), the U.S. is somewhat unique in the disclosure requirements 
applicable to such activity. Specifically, lobbyists - often organized in special interest groups can legally influence the policy formation process through two main channels. First, lobbyists are allowed to carry out lobbying activities in the executive and legislative branches of the government. Second, they can offer campaign finance contributions, in particular, through political action committees (PACs). In one respect, campaign contributions aim at putting or keeping the "right" candidates in office while lobbying expenditures seek to influence the opinion of those who are already holding the power to make the decisions.

Companies and other special interest groups spend billions of dollars each year to lobby the Congress and federal agencies. Some of these retain lobbying firms, many of them located along Washington's legendary K Street; others have lobbyists working in-house. Under the Lobbying Disclosure Act of 1995 (LDA), subsequently modified by the Honest Leadership and Open Government Act of 2007, all lobbyists (acting as intermediaries between legislators/regulators and clients with the aim to voice their opinion on various issues) have to file semi-annual reports to the Secretary of the Senate's Office of Public Records (SOPR), provided that they satisfy the conditions specified in the LDA.

"Lobbying activity" is defined in Section 3(7) of the LDA as "lobbying contacts or efforts in support of such contacts, including background work that is intended, at the time it was performed, for use in contacts, and coordination with the lobbying activities of others". While the exact nature of lobbying activities is somewhat elusive, the official description of a lobbyist in the Congress guide to the LDA is "any individual (1) who is either employed or retained by a client for financial or other compensation; (2) whose services include more than one lobbying contact; and (3) whose lobbying activities constitute 20 percent or more of his or her services 
during a three-month period." Any person meeting these criteria must register as a lobbyist under the Lobbying Disclosure Act.

In addition to lobbying, politically targeted activities involve financing of campaigns for elected officials and candidates. PACs, often representing business or ideological interest groups, are organized for the purpose of raising and spending money to elect and, sometimes, defeat particular candidates. The total amount PACs can contribute to an individual candidate's committee is capped: it cannot exceed $\$ 5,000$ per election (primary, general, or special). Similarly, they cannot give more than $\$ 15,000$ annually to any national party committee and $\$ 5,000$ annually to any other PAC. On the receiving side, they may receive up to $\$ 5,000$ from any one individual, PAC or party committee per calendar year. These limits are applied on a consolidated basis to affiliated PACs by treating them all as one entity. ${ }^{8}$

\footnotetext{
${ }^{8}$ The affiliations are based on the names of the connected organization PACs provide when they register with the Federal Election Commission (FEC). We refer the interested reader to the FEC website (http://www.fec.gov/) for more information on PACs. Also, note that the rules governing campaign contributions have changed significantly from what is described here in the wake of the 2010 Supreme Court decision commonly known as "Citizens United", which granted corporations, unions, and individuals the right to donate unlimited finds to outside groups to campaign for or against candidates. One byproduct of the decision was the "Super PACs", which do not have the same reporting requirements. Since these developments happened after the end of our sample period, the analysis is not affected by them.
} 


\section{Road to the Crisis}

Many observers claimed that regulatory failure was one of the culprits that paved the road to the financial crisis of 2007-08. In this section, we provide an overview of the key pieces of legislation that shaped the financial landscape prior to the crisis. ${ }^{9}$

Since the 1980 s, the U.S. financial regulatory system has been on a deregulatory process that, arguably, aimed to modernize the regulatory landscape and gained momentum in the late 1990s and early 2000s. There were several crucial steps in this process, starting with the repeal of the Glass-Steagall Act. The Financial Services Modernization Act of 1999 (FSMA) formally repealed the Glass-Steagall Act of 1933 (also known as the Banking Act of 1933) and related laws, which prohibited commercial banks from offering investment banking and insurance services. Once banks were allowed to engage in these services, activity in private-label securitization and derivatives markets stepped up. Yet, supplementary regulation to control the risks associated with these new services somewhat lagged behind: rules established by the Financial Accounting Standards Board allowed off-balance-sheet operations involving securitized loans, eliminating the need to hold capital reserves against such liabilities. The following year, the Commodity Futures Modernization Act of 2000 (CFMA) further enhanced the ability of commercial banks and other financial institutions by exempting financial derivatives, including credit default swaps, from regulation.

In parallel to legislation allowing commercial banks to expand their financial activities and get more interconnected with the rest of the financial system, there have been a couple of

\footnotetext{
${ }^{9}$ A full list of legislative proposals that got FIRE attention (indicated by being mentioned under specific issues in the lobbying reports) and their overview is in the Supplemental Appendix.
} 
important changes that relaxed rules pertaining mortgage loan business. Particularly, with the purpose "to expand homeownership", federal housing support programs, including downpayment assistance as well as insurance and other involvement by federal agencies, were boosted under the American Homeownership and Economic Opportunity Act of 2000 and American Dream Downpayment Act of 2003. A related bill was the FHA Multi Family Loan Limit Adjustment Act, which aimed to amend the National Housing Act to increase the mortgage amount limits applicable to FHA mortgage insurance for multifamily housing located in highcost areas. This bill never became law but passed the House in the 109th Congress.

Finally, significant changes to personal finance came with the Bankruptcy Abuse Prevention and Consumer Protection Act of 2005 (BAPCPA). The bill practically made it more difficult for people to file for bankruptcy, in particular by pushing borrowers to file a Chapter 13 bankruptcy (under which the debts are discharged only after the debtor has repaid some portion of these debts), instead of a Chapter 7 bankruptcy (under which most debts are forgiven or discharged).

Equally important to the passage of key "lax" bills is the fact that a stream of legislation proposals aiming to tighten regulations failed to pass the chambers and be enacted despite several rounds of attempts. In particular, bills targeting predatory lending practices and advocating consumer protection through education as well as by opening the litigation path for lending practices deemed to be unfair were introduced fifteen times in the House of Representatives and twice in the Senate, under different but similar names (e.g. Anti-Predatory Lending Act of 2000, Consumer Mortgage Protection Act of 2000, etc.). Only the House version 
dated 2007 (Mortgage Reform and Anti-Predatory Lending Act of 2007) was able to pass the House but it never got out of the Senate committee. ${ }^{10}$

To summarize, one should consider both lax and tight bills in order to get a complete picture and look carefully into the alleged regulatory failure. The following bills were key in shaping the financial regulation framework in the run-up to the financial crisis: Financial Services Modernization Act of 1999; Commodity Futures Modernization Act of 2000; American Homeownership and Economic Opportunity Act of 2000 and American Dream Downpayment Act of 2003; Bankruptcy Abuse Prevention and Consumer Protection Act of 2005; Proposals aiming to adjust the limits on FHA-insured loans; Anti-predatory lending legislation proposals that never got enacted. In our empirical analysis, we study the bills that were named in the lobbying reports, taking this as an indication that the financial industry revealed these bills to be relevant to their operations. In many cases, the bills named in the lobbying reports are different versions ('reincarnations') of this short list. The full list of the 47 bills included in the analysis and details on these bills are provided in Table A2 of the Supplemental Appendix.

\section{DATA AND METHODOLOGY}

\section{A. Data}

By its nature, our analysis requires non-standard data, sometimes only available from nontraditional sources. We explain the details of how we obtained our data in this section.

\footnotetext{
${ }^{10}$ The Frank-Dodd Wall Street Reform and Consumer Protection Act, signed into law on July 21, 2010, includes several provisions from these proposals.
} 


\section{Politically Targeted Activities}

Data on PAC contributions are available through the websites of the Federal Election Commission (http://www.fec.gov) and the Center for Responsive Politics (CRP, at www.opensecrets.org). PACs can be linked to a corporate or industry sponsor as well as, naturally, to a legislator. We first compile the PAC contributions to each legislator by every financial company that lobbied on the bills in our sample (or listed the name of the bill in its lobbying report). Then we sum the contributions to a particular legislator by all the firms affected by a particular bill. Hence, this gives us a measure of PAC contributions at the billlegislator level. Note that we have four congresses in our dataset from 1999 through 2006. The PAC contributions correspond to the election cycle during which the bill in question was introduced.

Detailed information on lobbying activities is available through lobbying reports from the SOPR (http://www.senate.gov/pagelayout/legislative/one_item_and teasers/opr.htm) and the CRP. A sample report can be found in Table A1 of the Supplemental Appendix. The reports list the name of the firm (e.g., Citigroup in Table A1) and the total dollar amount it spends on lobbying activities. The legislation requires the disclosure not only of the dollar amounts actually received/spent, but also of the issues for which lobbying is carried out. Thus, unlike PAC contributions, lobbying expenditures can be associated with targeted policy areas. Finally, the reports must also state the names of the lobbyists that worked on the specific issues reported on behalf of the client.

We extract the lobbying reports filed by financial institutions that engaged in mortgagemarket-related activities either directly (e.g., originating loans) or indirectly (e.g., securitizing 
loans originated by others). ${ }^{11}$ Our analysis distinguishes between lobbying activities that are related to financial-market-specific issues from other lobbying activities and matches the annual amounts to the year the issue of interest was discussed in the congress. We first concentrate only on issues related to the five general issues of interest (accounting, banking, bankruptcy, housing, and financial institutions) and then gather information on the specific issues, which are typically acts proposed at the House or the Senate, that were listed by the lobbyists as the main issue for the lobbying activity. ${ }^{12}$ Then, we go through these specific issues one by one and determine whether an issue can be directly linked to restrictions on mortgage market lending. For example, H.R. 1163 of 2003 (Predatory Mortgage Lending Practices Reduction Act) and H.R. 4471 of 2005 (Fair and Responsible Lending Act), regulating high-cost mortgages, are bills that we deem to be relevant to the mortgage market. On the other hand, H.R. 2201 of 2005 (Consumer Debt Prevention and Education Act) and the Sarbanes-Oxley Act of 2002, although in general related to financial services, do not include any provisions directly related to mortgage lending and are not classified as mortgage-market-specific issues. The final set of 47 bills we use in the analysis is the comprehensive set of financial-market-related issues mentioned by any of the institutions engaged in mortgage-market-related activities in the run-up to the crisis.

\footnotetext{
${ }^{11}$ The mortgage-market-related activities are identified using Home Mortgage Disclosure Act Database and this identification procedure takes into account not only the activities by the institution itself but also the activities by its related companies. See Igan, Mishra, Tressel (2011) for more details on the identification of these financial institutions.

12 'General issue area codes' are provided by the SOPR and listed in line 15 of the lobbying reports while the 'specific lobbying issues' are listed in line 16. See Supplemental Appendix for more details on what the reports look like and a full list of the specific issues selected for the analysis.
} 
After classifying all listed issues, we calculate lobbying expenditures on specific issues by splitting the total amount spent evenly across issues. To be more precise, we first divide the total lobbying expenditure by the number of all general issues and multiply by the number of general issues selected. Then, we divide this by the total number of specific issues listed under the five general issues and multiply by the number of specific issues of interest. ${ }^{13}$ In order to illustrate the construction of the final lobbying variable, suppose firm A spends $\$ 300$, and lobbies on 3 general issues (banking and housing - general issues of interest -- and trade - not a general issue of interest); it lists 2 specific issues under banking and housing (H.R. 1163, which is a relevant specific issue and H.R. 2201, which is not relevant). In this example, the final lobbying expenditure variable is calculated as $((300 / 3) * 2) / 2) * 1=\$ 100$.

We also get the lobbying expenditures by consumer advocacy groups who lobbied on the same bills. We split these expenditures among bills using the same procedure as the one explained above. Note that this procedure may not reflect the "true" amount spent on each issue but works as an approximation in the absence of such a split provided in the reports. We check the robustness of our results to an alternative splitting procedure as well as to alternative lobbying expenditure measures in Section IV.B.

\footnotetext{
${ }^{13}$ For robustness, we adopt an alternative splitting approach that distributes expenditures using as weights the proportion of reports that mention the specific issues of interest. We also consider lobbying expenditures by the financial industry associations. The list of member firms for each association in the lobbying database is compiled by going on each association's website. A portion of the associations' lobbying expenditures is assigned to each member firm based on the share of its own spending in the total of all members.
} 


\section{Network Connections}

We look into whether and how career paths of various legislators, lobbyists, and financial executives cross ('revolving door'). Our primary measure of network connections captures the association between the legislator and the lobbyists working on a particular bill. The variable is measured at the legislator-bill level and uses information on the professional background of the lobbyists hired to work on a particular bill. The names of the lobbyists are extracted from the lobbying reports whereas the information on the background of these lobbyists is compiled from various sources including the Washington Representatives, a directory published by Columbia Books in its suite of www.lobbyists.info products and www.opencongress.org.

We call this bill-legislator level variable, 'Connection between lobbyist and legislator'. It is defined as a dummy that equals 1 if at least one of the lobbyists working on a specific bill is connected to a particular legislator. This connection is defined either by the lobbyist having worked in that legislator's office ('Connection through legislator's office') or by the lobbyist having worked in a committee in which that legislator had a seat ('Connection through committee'). Conceptually, this measure is close to the one used in Blanes-Vidal, Draca, and Fons-Rosen (2011). The difference is that they look at the connections from an individual lobbyist's perspective while we construct our variable for each bill-legislator pair by determining whether any of the lobbyists that have worked on a particular bill were employed as staffers in the office of or in the committee associated with a specific legislator voting on that bill.

We also use a legislator-level variable to capture the connectedness of the legislators with Wall Street. This is a dummy that equals 1 if the legislator ever worked in FIRE (capturing the networks directly linking Wall Street to Capitol Hill). Labeled as 'Worked in Wall Street', the variable is similar in spirit to the definition of connections used in Faccio (2006), Faccio, 
Masulis and McConnell (2006)Braun and Raddatz (2009). We further distinguish this measure chronologically in an alternative construction so that it reflects whether the legislator worked in the financial industry after her time in public office. These variables are constructed using biographical information on the legislators from various sources, including www.opencongress.org.

Note that, while 'Connection between lobbyist and legislator' varies across bills as well as across legislators, 'Worked in Wall Street' variable is constant across bills. Hence, our estimates of the direct link of connectedness on voting behavior come from the specifications where we use the 'Connection between lobbyist and legislator' variable.

\section{Legislator Actions}

There are various points in the legislative process at which a legislator makes her stance on the proposed bill known to the others. Obviously, recorded votes on passage constitute one such point but, as mentioned earlier, not all bills get to this final stage. For those that do (10 out of a total of 47 bills), we obtain the roll call records for all senators and representatives from www.voteview.com, a website maintained by Keith Poole. For bills that never make it to the final voting stage (or do but do not have recorded votes), it is important to analyze the information hidden in the earlier stages of the legislative process. Put simply, lobbying may alter the path a bill takes from the very beginning. In order to explore what inferences one can make based on the observations concerning these bills, we gather data on the sponsorships and cosponsorships, which indicate support for a bill. The source in this case is www.govtrack.us. (Co-)sponsorship on a bill often translates into voting in favor of that bill; Mian, Sufi, and Trebbi (2010) also use co-sponsorship information in addition to actual votes in their analysis of legislative actions related to the expansion of subprime mortgages. 
We go over the details of each of the bills and categorize them into two types: (1) those promoting deregulation ('lax bills') and (2) those advocating tighter regulation of the activities of the lenders ('tight bills'). Importantly, not all filers necessarily report their stance on a given issue, e.g., whether they support the passage of a bill or not. Hence, we cannot make the distinction between lax and tight bills based on the positions taken by the financial institutions. Therefore, the approach we take is to use the content of the bills themselves to make this classification. The provisions of bills make such a lax-tight classification reasonably unambiguous: we define lax bills as those offering more options to the lenders in conducting their activities while tight bills impose restrictions on lending activities. For example, the American Dream Downpayment Act opens the door to lower downpayment loans, enhancing mortgage lending opportunities, whereas the Predatory Lending Consumer Protection Act introduces additional disclosure requirements and increases penalties for creditor violations.

The bills are further grouped into six categories based on their similarities to reflect the fact that the bills that end up in the same 'category' actually are a 'reincarnation' of each other (see Table 2 for the individual bill and category names). Each category and reincarnation pair defines an individual bill. Creating broad bill categories is important for our empirical strategy as it allows us to exploit the variation in legislators' stance across different reincarnations of the same bill category. Note that an ideal experiment could be to have two votes for the same bill, and compare the same type of action (a recorded vote); however, we do not have two roll calls for any of the bills in our sample. Classifying the bills into broad regulation proposals and combining the information on sponsorships allows us to conduct an experiment in a similar spirit. 
We translate the actions on bills with opposite implications for the financial industry to derive a common measure of stance on deregulation so that we can explore the relationship between lobbying, connections, and outcomes of the legislative process in a systematic manner. So, we construct a binary variable capturing the concept of favoring deregulation, which entails expressing support in favor of lax bills and against tight bills. To put it more precisely, we create a variable, "stance in favor of deregulation", as a dummy that takes the value 1 if on the particular lax bill in question, the legislator signed up as a (co-)sponsor or her vote was "aye" and 0 if she did not (co-)sponsor the bill or voted "nay". For a tight bill, this dummy takes a value of 1 if the legislator neither signed up as a (co-)sponsor nor her vote was "aye".

Our primary dependent variable in the empirical analysis measures the probability of a legislator switching her stance from being against to being in favor of deregulation. It is a dummy with value 1 if the legislator changed her vote from 'nay' ('aye') to 'aye' ('nay') on successive reincarnations of a lax (tight) bill if the bill was ultimately voted on. If the bill did not have a roll call, then we set the dummy to 1 if the legislator switched from not (co-)sponsoring a bill to (co-)sponsoring, if. For example, a legislator is defined to switch her stance if, say, within the category of "Predatory Lending Consumer Protection Act", she switches from being against the first reincarnation of the bill (H.R. 3901 -- Anti-Predatory Lending Act of 2000) to being in support of the second reincarnation of the same bill category (H.R. 4213 - Consumer Mortgage Protection Act of 2000). Note that if a legislator does not (co-)sponsor a lax bill and ends up voting for it in a successive reincarnation, we treat it as a switch in stance. However, such cases are limited (only 8 percent of observations with lax bills). 


\section{B. Empirical Specification}

The empirical approach we employ aims to exploit the variation across legislators and bills in terms of legislative outcomes and lobbying by FIRE. Our baseline regression equation is as follows:

$$
S_{i B R}=\alpha L_{B R}+\beta N_{i B R}+s_{i} * t_{c}+v_{B} * t_{c}+\mu_{R} * t_{c}+\varepsilon_{i B R}
$$

where $S_{i B R}$ is the switch in the stance of the legislator $i$ from being against to being in favor of deregulation across successive reincarnations $R$ of the same bill category $B$. Note that each pair of $B$ and $R$ uniquely identifies an individual bill. $L_{B R}$ is the log of the total amount of lobbying expenditures spent on the bill by the firms that were "affected" by the bill, as revealed by their decision to engage in politically targeted activities regarding this bill. Note also that $L_{B R}$ varies at the bill category-reincarnation level but does not vary at the legislator level, because the lobbying reports do not provide information on which individual legislators were contacted. Notice that, since lobbying expenditures are aggregated, any association we find with switching could be interpreted as either the direct link of lobbying to legislator $i$ or the indirect link of lobbying to legislator $j \neq i$ through strategic interaction among legislators such as bargaining on other bills or modification to the bill in question. $N_{i B R}$ is the 'Connection between lobbyist and legislator', which as discussed above aims to capture the network connections between the legislator and the lobbyists working on a particular bill.

In all the specifications, we employ the interaction between legislator and congress fixed effects, $s_{i} * t_{c}$. The legislator fixed effects, $s_{i}$, account for time-invariant legislator characteristics. The congress fixed effects, $t_{c}$, take into account the particular political environment (e.g., the balance between Republicans and Democrats) in a given political cycle, 
and indirectly, the circumstances in the financial markets and the broader economy, which may generate anti- or pro-regulation waves. For example, if there is any new economic or financial information that affects both the probability of switching and lobbying efforts, it would be captured by the congress fixed effects.

Importantly, the interaction terms $s_{i} * t_{c}$ control for any legislator characteristics that could vary across different congresses; for example, whether the legislator belongs to the same party as the chairman of Senate Banking and House Financial Services committees, whether the legislator belongs to the majority party. These would also capture the constituent interests, to the extent that these interests are invariant within a congress. For example, there could be changes in legislative priorities across congresses due to a shift in voter preferences. These changes could also affect lobbying efforts. Such effects would be controlled for by the interaction term. In addition, potential changes in a legislator's general propensity to switch stances across time (for example, because the legislator gains more experience) would also be captured by $s_{i} * t_{c}$.

We also employ the interaction between bill category and congress fixed effects, $v_{B} * t_{c}$. The bill category fixed effects, $v_{B}$, control for any unobserved characteristics of a certain regulation proposal. The inclusion of this set of fixed effects is crucial to our empirical strategy as it allows us to compare the change in a legislator's stance across different reincarnations of the same issue. The interaction terms $v_{B} * t_{c}$ would then capture any factor that would affect the stance on a given regulation proposal over time. For instance, a Democratcontrolled congress may be more in support of the American Dream Downpayment Act than a Republican-controlled one, and observing the general stance on a bill may affect an individual legislator's position. 
Finally, we also include the interaction between reincarnation and congress fixed effects, $\mu_{R} * t_{c}$. These control for unobserved reincarnation-specific effects, for example, increasing probability of a switch on later reincarnations due to more aggressive lobbying or longer negotiation and bargaining or learning about others' positions by observing the votes in the earlier reincarnations. In other words, if there is a tendency towards increased lobbying and, at the same time, a tendency towards increasing support for a bill across successive reincarnations, the reincarnation fixed effects would capture such common trends. However, as we discuss below, we do not necessarily observe increasing lobbying expenditures across successive reincarnations.

Given that our empirical strategy is based on utilizing variation in a legislator's stance across successive reincarnations within a bill-category, we cannot introduce individual bill $\left(v_{B} * \mu_{R}\right)$ fixed effects. In order to account for certain bill characteristics, we include in all the specifications, a proxy for the complexity of the bill. Arguably, more complex bills are likely to be associated with more intense lobbying and discussions. At the same time, the complexity of a bill may also be linked to the likelihood of a legislator switching her stance because, e.g., the legislator may take more time to absorb the content of all the provisions and make a decision. We construct a measure of complexity by calculating the total number of pages that describe and contain the full text of a bill. In addition, all regressions include a dummy for tight bills.

Finally, the standard errors in all the regressions are clustered at the legislator-level to account for the correlation in a legislator's stance across different issues. ${ }^{14}$

\footnotetext{
${ }^{14}$ Our results are robust to clustering at the bill-category and legislator-category levels.
} 


\section{RESUlTS}

\section{A. First Look}

As shown in Table 1, between 1999 and 2006, interest groups have spent on average about $\$ 4.2$ billion per political cycle on targeted political activity, which includes PAC campaign contributions and lobbying expenditures. Lobbying expenditures represent by far the bulk of all interest groups' money spent on targeted political activity (close to 90 percent). Expenditures by FIRE companies constitute roughly 15 percent of overall lobbying expenditures in any election cycle. Approximately 10 percent of all firms that lobbied during this time period were associated with FIRE. Notably, overall lobbying expenditures as well as expenditures by FIRE have increased by roughly two-thirds between 1999 and $2009 .^{15}$

All these indicate that, during our sample period, FIRE was one of the most politicallyactive industries. The focus of these intense activities was a small set of regulation proposals. In particular, when bills with the same/similar name introduced more than once are consolidated together in one broad concept category, there were only six proposals that lobbying activities of the financial industry targeted. Partially as a reflection of the legislative process, these proposals were introduced in various reincarnations, sometimes as frequently as 15 times. As summarized in Table 2, lobbying efforts on different reincarnations within a bill category are somewhat evenly distributed across time. Hence, lobbying on a particular issue is not necessarily front- or back-loaded and seems to be quite persistent through the attempts to turn a proposal into law.

\footnotetext{
${ }^{15}$ Drutman (2010) describes the growth of modern corporate lobbying and argues that corporate lobbying activity is likely to continue to expand in the future, with large corporations playing an increasingly central role in the formulation of national policies.
} 
As a first pass in looking into the relationship between the financial industry's politically targeted efforts and financial regulation during 1999-2006, we calculate the probability that a bill ultimately gets signed into law. Table 3 presents these results. On the individual bills, no tight bill passed both chambers of Congress and ultimately got signed into law while 16 percent of the lax bills did. This difference is even more striking when individual bills are grouped into common concept categories. Actually, the majority of lax regulation proposals (three out of five) were ultimately signed into law whereas none of the tight regulation proposals succeeded. Perhaps even more striking is the fact that anti-predatory lending consumer protection proposals were never signed into law in spite of 15 attempts (Table 2).

In what follows, we analyze whether the pattern shown in Table 3 survives formal econometric analysis. Summary statistics on the variables used in the empirical analysis are shown in Table 4. In total, we consider 47 bills in the analysis. ${ }^{16}$ In the four congresses covered in our dataset, there were 790 legislators that voted on at least one of these bills. FIRE companies hired 575 lobbyists to lobby on these bills. On average, roughly $\$ 4$ million were spent on a bill. ${ }^{17}$ The bill with highest lobbying spending by the FIRE was H.R. 833 Responsible Lending Act introduced in the $108^{\text {th }}$ Congress as the $9^{\text {th }}$ reincarnation of Predatory Lending Consumer Protection Act. In comparison, campaign contributions by the affected firms to the

\footnotetext{
${ }^{16}$ Initially, we identify 51 relevant bills discussed in the period between 1999 and 2006 . However, four of these bills are dropped in the analysis due to various data issues, see Supplemental Appendix for details.

${ }^{17}$ Note that this statistic is not for the aggregate amount spent by the financial firms which lobbied on the bills in our sample. Rather, it is for the part of the aggregate amount we allocate to the bills in question by these firms. The aggregate lobbying expenditure by the affected firms on all bills was three times as large.
} 
legislators were minuscule standing approximately at an average of $\$ 2,000$. Lobbying expenditure by the "other side", i.e., the consumer organizations, was also very small (roughly $\$ 20,000)$ compared to the amount spent by the financial firms. Of all the legislators in the data set, 14 percent are connected to Wall Street. Among the bill-legislator observations, 32 percent indicate a connection between the legislator and the lobbyists working on the bill. Overall, connections between Wall Street and Capitol Hill (as illustrated by the 'Worked in Wall Street' variable) and the 'Connection between lobbyist and legislator' variable) are not rare occurrences and there is enough variation in these measures for regression analysis. Looking at the dependent variable, the switch from being opposed to deregulation to being in favor occurs in 6 percent of the legislator-bill category-reincarnation observations. ${ }^{18}$ Importantly, these switch cases are not confined to a particular group of legislators or a particular bill category. In fact, the switch cases are spread across all bill categories and 71 percent of the legislators have switched at least once.

\section{B. Regression Analysis}

\section{Main Findings}

The results from estimating our baseline specification, Equation (1), are presented in Table 5. We find a statistically significant, positive association between money spent on lobbying for a particular bill and legislators switching their stance in favor of deregulation (Table 5, Column

\footnotetext{
${ }^{18}$ Note that this fraction goes up to 10 percent in the specifications where certain non-switch cases are dropped. See the discussion of alternative dependent variables in Section IV.B.
} 
I). ${ }^{19}$ This association is also significant in economic terms: a one standard deviation increase in log lobbying expenditures corresponds to a 37 percentage-point increase in the probability of a legislator switching to being in favor of deregulation.

Network connections between the legislators and the lobbyists also have a link to securing a switch in favor of deregulation. Specifically, if the lobbyist hired to contact the legislator on a bill has an employment history connecting the lobbyist to that legislator, the higher the likelihood that the legislator switches her stance (Table 5, Column II). On average, connections between the lobbyist and the legislator are associated with an increase in the probability of switching in favor of deregulation by 2.5 percentage points.

In Columns III and IV, we investigate whether this association between lobbying and switching is stronger when it occurs through connected rather than unconnected lobbyists. The coefficient on lobbying almost doubles when the lobbying money is spent through connected lobbyists. In other words, connected lobbyists are twice as efficient. This finding is consistent with others in the literature emphasizing the importance of the value of connections.

Next, we explore how legislator characteristics affect the relationship between lobbying, hiring connected lobbyists and the probability of changing a legislator's stance. We estimate a specification where we introduce the interaction between the lobbying and connection variables, and a measure of legislators' conservative tendencies. We borrow the $D W$-nominate variable calculated by Poole and Rosenthal (2007). These ideology scores are higher for more conservative legislators. As an alternative to the ideology score, we use a dummy variable that is

\footnotetext{
${ }^{19}$ Our results are robust to estimation by probit. However, we prefer the linear probability model as our baseline as introducing fixed effects in a probit model may be prone to inconsistent estimates due to the incidental parameter problem (Chamberlain, 1984).
} 
1 if the legislator is a Republican. The interaction of the legislator's conservatism and lobbying has a positive and significant coefficient (Table 6, Columns I and II). Hence, higher lobbying expenditures may be more effective in persuading more conservative legislators. For the most conservative legislator, a one standard deviation increase in log lobbying expenditures is associated with a 39.7 percentage-point increase in the probability of taking a stance in favor of deregulation (Table 6, Column I). However, the ideology of the legislator does not change the relationship between connections and switching (Table 6, Columns III and IV). This may indicate that, irrespective of their ideology, all legislators are equally likely to be influenced by a lobbyist who is connected to them.

Then, we look into how legislator's work experience comes into play with the relationship we have established between lobbying and switching in favor of deregulation. The link between lobbying expenditures to voting patterns is enhanced by the legislators' experience in Wall Street (Table 6, Column V). In particular, lobbying is more likely to be associated with a positive probability of moving votes towards deregulation if the legislator ever worked in the financial industry. For legislators that are "Wall Street insiders", lobbying is linked to a 2.1 percentage-point higher probability of taking a stance in favor of deregulation. The results appear to be driven by experience prior to taking office (Table 6, Column VI). Specifically, working in Wall Street after serving in Congress does not enhance the link between lobbying and the probability of switching. Hence, we do not find any evidence suggesting that the promise of a job in Wall Street affects stance on regulation. Rather, legislators that have financial industry 
work experience are more likely than those that do not to change their position by lobbying on a deregulation proposal. $^{20}$

PAC contributions have been commonly used in the literature to measure politically targeted activities. Although the magnitude of PAC contributions is small relative to lobbying expenditures and PAC contributions cannot be linked to particular issues, the distinctive feature of these contributions is that they are linked to particular legislators, and thus, may influence individual voting patterns directly. Therefore, we repeat the analysis in Table 5 using PAC contributions by affected firms instead of lobbying expenditures. ${ }^{21}$ Table 7 shows the results. While the findings are qualitatively similar to those in Tables 5 and 6 , the estimated effects are much smaller in magnitude. For example, a one standard deviation increase in log PAC contributions is associated with only a 0.9 percentage-point increase in the probability of switching in favor of deregulation (Table 7, Column I).

There are two plausible explanations for the weaker links between campaign contributions and voting patterns. First, PAC contributions themselves are minuscule compared to lobbying expenditures (Table 4). Second, endogeneity is potentially more of a concern. ${ }^{22}$

\footnotetext{
${ }^{20} \mathrm{We}$ also looked at whether the legislator's K Street experience enhances the link between lobbying and switching: 18 percent of legislators have such experience and 92 percent of those with K Street experience acquire such experience following their public service. We did not find any significant coefficient on the interaction of K Street experience and lobbying, even for experience as a lobbyist after public office.

${ }^{21}$ PAC contributions by affected firms and lobbying expenditures on a given bill are positively correlated so we prefer not to include both in the same specification. The results are unchanged when we do.

${ }^{22}$ Endogeneity concerns could be addressed more directly if we restrict the sample only to the legislators that announce their decision not to run for office in the next election cycle. Unfortunately, we do not have enough
} (continued...) 
This is because we construct this variable at the bill-legislator level. In particular, PAC contributions are targeted to particular political candidates. Hence, the affected firms may allocate their contributions based on the likelihood with which they think the candidate will act in favor of deregulation once she comes into office. By comparison, lobbying expenditures are targeted to particular issues rather than explicitly to particular legislators and are measured at the bill level, alleviating some of the endogeneity concerns but, unfortunately, not fully eliminating all of them.

In a nutshell, the analysis points to strong evidence that the likelihood of a legislator changing her stance on financial regulation proposals introduced in the run-up to the crisis was linked to the lobbying efforts and network connections. In addition, the evidence suggests that spending more by hiring connected lobbyists rather than unconnected ones gets the financial industry more bang for their buck.

\section{Robustness}

\section{Alternative controls}

Although we control for unobserved time-invariant and time-varying legislator, bill category and reincarnation characteristics in the baseline specification, we cannot introduce bill categoryreincarnation or legislator-bill category-reincarnation fixed effects. In what follows, we discuss several factors that could be influencing the probability of switch and the intensity of lobbying that vary along these dimensions and check the robustness of our results to these factors.

observations for such an analysis since we have only 37 legislators announcing their retirement in our sample period to run our baseline specification with the full set of fixed effects. In a specification without any fixed effects, we do find a statistically significant positive association between the probability of switching and PAC contributions. 


\section{Voting history of the legislator}

Reputational or public image concerns may influence legislators to keep a consistent stance on a particular issue. Hence, the probability of switching in subsequent reincarnations of the same bill may be affected by how the legislator voted on the earlier versions. At the same time, legislators' voting record could influence the intensity of lobbying activities on a given bill. In order to address this concern, we introduce a variable indicating the stance of the legislator on a particular bill in the previous three reincarnations. The coefficients on lobbying expenditures and connections are mostly unchanged although we do find evidence that the voting history of

the legislator is related to her probability of switching (Table 9, Columns I and II). Particularly, if a legislator has been against a deregulation proposal in the past, she is more likely to switch to being in favor. This may indicate that legislators take time to learn more about a bill before deciding to switch.

\section{Voting along party lines}

Legislators may also switch their position on a particular bill not because of lobbying but because a large number of their party members decide to support a deregulation bill. In order to control for the switch occurring due to such "herd behavior", we add a variable that is constructed as the number of legislators in the same party as the particular legislator that decide to switch. The results, shown in Table 9, Columns III and IV, affirm that the importance of lobbying and connections in explain the probability of switch even after controlling for potential pressure from other party members. 
Modifications to the bill across reincarnations

Another possible explanation for a legislator to be initially against deregulation but then show support could be the changes to the content of the bill as it evolves across successive reincarnations. Note also that the content of a bill may change precisely due to lobbying efforts. $^{23}$ We introduce the number of new amendments added to a bill in its successive reincarnations to address this issue. The coefficient on lobbying expenditures remains positive and significant but reduces by almost a third, which suggests that additional amendments are indeed correlated with lobbying expenditures (Table 9, Columns V and VI).

\section{Lobbying by those other than the financial industry}

Does lobbying by the "other side" or opposing forces affect our results? Unfortunately, it is hard to find a good measure of the opposing forces because these may include not only financial institutions that are against deregulation and organized special interest groups (e.g., consumer organizations) but also other interested parties whose lobbying may go totally unreported (e.g., federal bank supervisors or the general public). In particular, we would ideally have a measure that captures the strength of opposition to a proposed bill from the regulators and the general

\footnotetext{
${ }^{23}$ Another reason for modifications to the bill may also be a consequence of strategic interactions among legislators where those in favor of deregulation agree to modify the bill in order to get other legislators on board.
} 
public as well as the groups that lobby on their behalf. ${ }^{24}$ In the absence of such a measure, we use data on lobbying activity by consumer organizations to construct a proxy for such opposing forces. In particular, we construct an indicator variable that is 1 if lobbying expenditures by consumer organizations on a given bill is positive. ${ }^{25}$

Interestingly, we find that lobbying by consumer organizations is positively correlated with lobbying by the financial industry as well as the probability of switching a legislator's stance in favor of deregulation (Table 9, Columns VII and VIII). This seems to suggest that lobbying by consumer organizations works in the same direction as lobbying by the financial industry. One explanation for this finding could be that some of the bills under consideration were perceived to be consumer-friendly as well. For example, bills promoting lower down payment requirements to enhance home ownership also helped many constrained borrowers take out mortgages. Importantly, the coefficient on lobbying by the financial industry remains unchanged.

\section{Momentum for deregulation}

\footnotetext{
${ }^{24}$ Another way of putting this is thinking of the analogous case of the financial firms: lobbying by the industry associations is part of the effort these firms exert on a proposed bill. As noted above, we check the robustness of our findings by including the lobbying expenditures by these associations.

${ }^{25}$ There are very few consumer groups who report lobbying on mortgage-market related issues. Also, their spending is quantitatively very small - on average, they spend about $\$ 20,000$ on a bill, which is less than one percent of the spending by the financial industry on these issues. Moreover, they lobby on only a small set of bills (roughly onethird).
} 
One could argue that there has been a pro-finance shift in sentiment, and at the same time lobbying expenditures have been steadily increasing (e.g. see Drutman, 2010); and that our estimates capture this unobserved latent momentum in support for deregulation and incentives for firms to lobby. Note that congress fixed effects control for any such common momentum in deregulation as well as lobbying over time (as long as it affects all legislators and billcategories). However, we also explicitly control for a time trend (Table 9, Columns IX and X). We continue to find a strong and positive link. Another argument could be that momentum for deregulation may emerge within a congress. Such effects would be captured by $\mu_{R} * t_{c}$ interactions.

\section{Alternative dependent variables}

The dependent variables in all the regressions above is a dummy variable that takes a value of one if the legislator's stance changes from being against to being in favor of deregulation. In all other cases, the dummy variable takes a value of zero. The dummy variable takes a value of zero if the legislator switched her stance from being in favor to going against deregulation, or if the legislator did not change her stance (she was initially against in the previous reincarnation and remained against in the current reincarnation; or if she was initially for deregulation, and remained so). For robustness, we take a closer look at these alternatives. We construct two alternative dependent variables restricting the cases where the dummy can take a value of zero. First, we drop those observations where the legislator sways her vote from being in favor to moving against deregulation, i.e., the relevant comparison is only between those who switch and those who stay put. Second, we further refine the comparison group, and the dummy variable takes a value of zero only for those observations where the legislator was against deregulation in 
the previous reincarnation of the bill and continues to remain against in the current reincarnation. The results are shown in Columns I-IV of Table 10. The estimated coefficients on the lobbying variable continue to be positive and statistically significant. The magnitudes are similar to the baseline regressions presented in Table 5. Yet, we do find weaker link for connections when we restrict the comparison group to those observations where the initial stance of the legislator is against deregulation. Next, we focus specifically on the switch in stance from being in favor to going against deregulation. We ask the question: do lobbying and network connections matter also in swaying the vote in the opposite direction? The evidence does suggest so for lobbying expenditures: more intensive lobbying does indeed reduce the probability that the legislator switches her stance from being in favor to going against deregulation (Table 10, Columns V-VI). Connections, again, seem to play a smaller role in explaining the switch in the opposite direction. Next, instead of the switch variable being a dummy, we define the switch in stance as taking 3 values: -1 if there is a switch from being against to being in favor of deregulation; 0 if the stance remains the same, and +1 if the stance switches from being against to moving in favor of deregulation. The results shown in Table 10, Columns VII-VIII, suggest that the lobbying continues to have a strong and positive link to swaying votes towards deregulation, and the link for connections remains robust. The magnitude of the estimated coefficient on lobbying is larger than that in the baseline specification (Table 5, Column I).

In all the regressions so far, our dependent variable is the switch in the stance of the legislator. Another relevant question we can ask is whether lobbying and connections have any link to the level of the legislator's position (rather than the switch). In order to address this question, we repeat our baseline regression changing the dependent variable to a dummy equal to one if the legislator is in favor of deregulation (i.e., expressing support in favor of lax bills and 
against tight bills). The results shown in Columns IX and $\mathrm{X}$ in Table 10 suggest that lobbying and connections are also significantly related to the position of the legislator. Note that the coefficient on lobbying is smaller than the baseline regression in Table 5, Column 1. Thus, lobbying seems to have a greater association with switching the legislators' position than with the position itself. One possible explanation for this finding is that lobbying is more likely to be endogenous to the position of the legislator rather than the switch in his stance.

Finally, in the baseline specification, following the previous literature (Mian, Sufi, and Trebbi, 2010) we used the information on sponsorships to create a measure of the broad stance for deregulation. One can argue that sponsorship may not be an accurate indicator of voting behavior. What if the restrict the analysis to only those bills which have recorded data on votes? In a restricted specification with a smaller set of fixed effects, we constrain the analysis only to such observations. The coefficient on lobbying (shown in Column XI, Table 10) remains robust, the magnitude being similar to the baseline specification. But we do not have enough variation to look at the link for connections (while controlling for all time-invariant legislator characteristics).

\section{Alternative explanatory variables}

We conduct robustness tests for sensitivity to the measurement of lobbying expenditures by recalculating this variable by: (i) taking into account lobbying expenditures by bankers' and other industry associations, (ii) not splitting lobbying expenditures by individual bills, and (iii) splitting lobbying expenditures among individual bills based on weights indicated by the share of 
reports filed by the firm in which a bill was listed. Table 11 presents the results, attesting that the findings from Table 5 remain largely unaltered. ${ }^{26}$

\section{Discussion of Findings}

Do our results imply that the lobbying efforts of the financial industry were "successful"? Recall that the lobbying reports do not always explicitly state the stance of the filer on a given issue, e.g., whether it supports the passage of a bill or not. There could be financial institutions that are against deregulation; for example, lenders with more prudent standards may prefer tighter rules to suppress competition by less prudent lenders. However, if we make the plausible assumption that the financial institutions were on average in favor of deregulation, our empirical results suggest that the lobbying efforts were successful in obtaining this outcome. Such an assumption indeed seems plausible since some financial institutions explicitly state their position on certain bills: for example, Bear Stearns in lobbying on the Mortgage Reform and Anti-Predatory Lending Act expressed that "advocated the concepts in the proposal but not the proposal".

Although our specification exploits variation in voting patterns for a given legislator on the same issue, can we interpret the findings as evidence of a causal relationship? One might

\footnotetext{
${ }^{26}$ In addition to the robustness checks discussed so far, we also do the following: (i) split the sample for tight and lax bills, (ii) split the sample for House and Senate bills, and (iii) control for lobbying expenditures by affected firms on issues unrelated to financial regulation. The positive and statistically significant coefficients on lobbying expenditures and connections survive these robustness checks. We also check the robustness of the results in Columns III-IV of Table 5 to alternative dependent and explanatory variables and controlling for lobbying by the other side. The finding that lobbying is more strongly associated with switching when connected lobbyists are hired is robust. Finally, we use the change in log lobbying expenditures and PAC contributions (rather than levels in the baseline regressions) across successive reincarnations and obtain significant and positive effect of connections and lobbying. These results are available upon request.
} 
argue that lobbying efforts are allocated towards legislators that already have an inherent tendency to switch their stance in favor deregulation, and hence we may be overestimating the effect of lobbying. Several considerations ameliorate but, unfortunately, do not fully eradicate such reverse-causality concerns. First, such tendencies would be captured by the legislator and congress fixed effects and their interactions in our empirical specification. Second, lobbying expenditures are not measured at the legislator level. The information we obtain from the lobbying reports does not include any reference to particular legislators. ${ }^{27}$ Hence, lobbying expenditure on a bill as a whole is unlikely to be directly influenced by voting patterns of any specific legislator.

Similar endogeneity concerns may apply to network connections. One can argue that a lobbyist's decision to work for a particular legislator may be influenced by the legislator's tendency to switch. However, connections are determined based on past employment histories. Therefore, they are not likely to be affected by voting patterns on particular regulation proposals in the future.

One can also argue that firms may be likely to hire lobbyists who are connected to legislators with a higher inclination to switch. Several factors alleviate such endogeneity concerns. First, such tendencies would be captured by the legislator and congress fixed effects and their interactions in our empirical specification. Second, when we look at the choice of hiring lobbyists, we see a reasonable degree of persistence. Specifically, the percent of lobbyists

\footnotetext{
${ }^{27}$ The LDA does not require a description of the specific recipients of and the specific activities funded by lobbying money. It is possible that certain legislators are contacted more often or lobbied more aggressively. However, if the lobbying activity involves "research and background work" to create arguments for or against a regulation proposal, information generated by such activities is likely to be accessible by other legislators as well.
} 
who worked on successive reincarnations (i.e., worked on $\mathrm{n}^{\text {th }}$ and $(\mathrm{n}-1)^{\text {th }}$ reincarnations) within the same bill category is very high (Table 8). For example, at least 90 percent of the lobbyists working on a reincarnation of the American Dream Downpayment Act had also worked on the previous reincarnation. Given this persistence, it would be hard to argue that firms systematically change their lobbyist-hiring patterns based on legislators' stance.

That said, the data and the empirical setup does not allow us to fully rule out other stories, e.g., if lobbying efforts are focused on proposals that are close calls or are the subject of intense debate and, as such more likely to be re-written, because we do not observe voting twice on the same exact bill but only in their similar versions ('reincarnations'). Overall, it may seem to be the case that lobbying and network connections sway votes from being against to being in favor of deregulation rather than the tendency to switch positions on a bill determining lobbying expenditures and how connections are established. But the evidence is not definitive in establishing this causal link.

\section{Conclusion}

Regulatory failure has been the subject of intense debate in the aftermath of the global financial crisis. In this paper, we take a closer look into the financial regulation proposals prior to the crisis and analyze how political influence was linked to the congressional actions on these proposals.

We use a detailed dataset that summarizes the politically targeted activities of the financial industry from 1999 to 2006, which includes the bills targeted, lobbyists hired, lobbying expenditures and campaign contributions, and measures of network connections of lobbyists and financial firms with legislators. We document that the probability of a bill advocating regulations 
less favorable to the financial industry being passed was lower than that of a bill promoting deregulation.

We provide robust evidence that lobbying expenditures by the affected firms and network connections between lobbyists and legislators were associated with whether the legislators switched their stance in favor of these bills. Additionally, hiring connected lobbyists significantly enhances this association.

These results give support to the notion that political influence of the financial industry may have played a role in shaping the regulatory landscape in the run-up to the crisis and that financial reform proposals should not be considered in isolation from these political economy factors. 


\section{References}

Acemoglu, Daron, 2009, "The Crisis of 2008: Structural Lessons for and from Economics," mimeo, MIT.

Benmelech, Efraim and Tobias J. Moskowitz, 2010, “The Political Economy of Financial Regulation: Evidence from U.S. State Usury Laws in the 19th Century," Journal of Finance, vol. 65 (3), pp. 1029-1073.

Bertok, Janos, 2008, "Lobbyists, Governments and Public Trust: Building a Legislative Framework for Enhancing Transparency and Accountability in Lobbying," OECD Report.

Bertrand, Marianne, Matilde Bombardini, and Francesco Trebbi, 2011, "Is It Whom You Know or What You Know? An Empirical Assessment of the Lobbying Process," NBER Working Paper No. 16765, February.

Blanes-Vidal, Jordi, Mirko Draca, and Christian Fons-Rosen, 2011, "Revolving Door Lobbyists," conditionally accepted, American Economic Review.

Braun, Matias and Claudio Raddatz, 2009, "Banking on Politics," World Bank Policy Research Working Paper Series No. 4902.

Center for Responsive Politics, 2009, http://www.opensecrets.org/lobby/background.php?id=F\&year=2010.

Chamberlain, G., 1984, Panel Data, in Griliches, Z., Intriligator, M.D. (Eds.), Handbook of Econometrics, Vol. 2, North-Holland: Amsterdam.

Cooper, Michael J., Huseyin Gulen, and Alexei V. Ovtchinnikov, 2010, “Corporate Political Contributions and Stock Returns," Journal of Finance, vol. 65 (2), pp. 687-724. 
Dagher, Jihad and Ning Fu, 2011, "What Fuels the Boom Drives the Bust: Regulation and the Mortgage Crisis," IMF Working Paper No. 11/215.

Drutman, Lee Jared, 2010, “The Business of America is Lobbying: The Expansion of Corporate Political Activity and the Future of American Pluralism", dissertation, University of California, Berkeley.

Faccio, Mara, Ronald W. Masulis, and John J. McConnell, 2006, "Political Connections and Corporate Bailouts,” Journal of Finance, vol. 61 (6), pp. 2597-2635.

Faccio, Mara, 2006, “Politically Connected Firms," American Economic Review, vol. 96 (1), pp. 369-386.

Fisman, Raymond, 2001, "Estimating the Value of Political Connections," American Economic Review, vol. 91, pp. 1095-102.

Igan, Deniz, Prachi Mishra, and Thierry Tressel, 2011, “A Fistful of Dollars: Lobbying and the Financial Crisis," NBER Macroeconomics Annual, vol. 26.

Johnson, Simon, 2009, "The Quiet Coup," The Atlantic, May; available at http://www.theatlantic.com/doc/200905/imf-advice.

Kroszner, Randall S. and Philip E. Strahan, 1999, "What Drives Deregulation? Economics and Politics of the Relaxation of Bank Branching Restrictions," Quarterly Journal of Economics, 114(4), pp. 1437-67.

Labaton, Stephen, 2009, “Ailing, Banks Still Field Strong Lobby at Capitol,” The New York Times, June 04; available at 
http://www.nytimes.com/2009/06/05/business/economy/05bankrupt.html?_r=2\&th\&emc =th.

Luce, Edward, 2009, "US banks spent $\$ 370$ million to fight rules," The Financial Times, May 06, available at: http://www.ft.com/cms/s/0/a299a06e-3a9f-11de-8a2d$\underline{00144 \text { feabdc } 0 . h t m l \text { ?nclick_check }=1}$.

Mian, Atif, Amir Sufi, and Francesco Trebbi, 2010a, "The Political Economy of the U.S. Mortgage Default Crisis," American Economic Review, vol. 100 (5), pp. 1967-98.

Mian, Atif, Amir Sufi, and Francesco Trebbi, 2010b, "The Political Economy of the Subprime Mortgage Credit Expansion,” working paper.

Obstfeld, Maurice and Kenneth Rogoff, 2010, "Global Imbalances and the Financial Crisis: Products of Common Causes," paper prepared for the Federal Reserve Bank of San Francisco Asia Economic Policy Conference, Santa Barbara, CA, October 18-20.

Poole, Keith and Howard Rosenthal, 2007, Ideology and Congress, Transaction Press: Piscataway: NJ.

Rajan, Raghuram and Luigi Zingales, 2003, “The Great Reversals: The Politics of Financial Developments in the Twentieth Century, Journal of Financial Economics, vol. 69, pp. 550.

Simpson, Glenn, 2007, “Lender Lobbying Blitz Abetted Mortgage Mess," The Wall Street Journal, December 31; available at http://online.wsj.com/public/article print/SB119906606162358773.html.

Stratmann, Thomas, 2002, "Can Special Interests Buy Congressional Votes? Evidence from Financial Services Legislation,” Journal of Law and Economics, vol. 45 (2), pp. 345-73. 
Table 1. Targeted Political Activity Campaign Contributions and Lobbying Expenditures (millions of dollars)

\begin{tabular}{lrrrr}
\hline \hline Election cycle & $1999-2000$ & $2001-02$ & $2003-04$ & $2005-06$ \\
Contributions from PACs & 326 & 348 & 461 & 509 \\
Overall lobbying expenditure & 2,972 & 3,348 & 4,081 & 4,747 \\
Of which expenditure by finance, insurance, and real & & & & \\
$\quad$ estate industry (FIRE) & 437 & 478 & 645 & 720 \\
$\quad$ Share of FIRE in overall lobbying (in percent) & 14.7 & 14.3 & 15.8 & 15.2 \\
Total targeted political activity & 3,298 & 3,696 & 4,542 & 5,256 \\
\hline
\end{tabular}

Source: Center for Responsive Politics. 
Table 2. Lobbying Expenditures on Reincarnations of Bills

(in percent of total spent on all attempts)

\begin{tabular}{|c|c|c|c|c|c|c|c|}
\hline Reincarnation & $\downarrow \backslash$ Category $\longrightarrow$ & $\begin{array}{l}\text { Commodity } \\
\text { Futures } \\
\text { Modernization } \\
\text { Act }\end{array}$ & $\begin{array}{c}\text { Bankruptcy } \\
\text { Abuse } \\
\text { Prevention and } \\
\text { Consumer } \\
\text { Protection Act }\end{array}$ & $\begin{array}{c}\text { American } \\
\text { Dream } \\
\text { Downpayment } \\
\text { Act }\end{array}$ & $\begin{array}{l}\text { FHA Multifamily } \\
\text { Housing } \\
\text { Mortgage Loan } \\
\text { Limit Adjustment } \\
\text { Act }\end{array}$ & $\begin{array}{l}\text { Predatory } \\
\text { Lending } \\
\text { Consumer } \\
\text { Protection Act }\end{array}$ & $\begin{array}{c}\text { Financial } \\
\text { Services } \\
\text { Regulatory Relief } \\
\text { Act }\end{array}$ \\
\hline & 1 & 52 & 30 & 10 & 14 & 5 & 4 \\
\hline & 2 & 29 & 1 & 8 & 17 & 4 & 27 \\
\hline & 3 & 19 & 1 & 18 & 5 & 5 & 14 \\
\hline & 4 & & 11 & 19 & 3 & 5 & 19 \\
\hline & 5 & & 34 & 7 & 52 & 10 & 20 \\
\hline & 6 & & 22 & 7 & 8 & 2 & 17 \\
\hline & 7 & & 1 & 3 & & 6 & \\
\hline & 8 & & & 14 & & 4 & \\
\hline & 9 & & & 9 & & 29 & \\
\hline & 10 & & & 5 & & 6 & \\
\hline & 11 & & & & & 3 & \\
\hline & 12 & & & & & 6 & \\
\hline & 13 & & & & & 11 & \\
\hline & 14 & & & & & 1 & \\
\hline & 15 & & & & & 3 & \\
\hline
\end{tabular}

Notes: The bills are grouped into six categories based on their similarities in their titles, descriptions, and provisions. Each attempt to pass a bill in a given category is labeled as a 'reincarnation'. The names of the bills brought forward in various attempts under the same broad concept are as follows: Commodity Futures Modernization Act - 1. H.R. 4541, 2. S. 2697, 3. H.R. 5660; Bankruptcy Abuse Prevention and Consumer Protection Act-1. H.R. 975, 2. H.R. 1529, 3. H.R. 1860, 4. S. 1920, 5. S. 256, 6. H.R. 685, 7. H.R. 2060; American Dream Downpayment Act - 1. H.R. 1776, 2. H.R. 5640, 3. H.R. 3206, 4. S. 1620, 5. H.R.1276, 6. S.811, 7. H.R. 3755, 8. H.R. 5121, 9. S. 3535, 10. S. 2169; FHA Multifamily Housing Mortgage Loan Limit Adjustment Act - 1. H.R. 1629, 2. S. 1163, 3. H.R. 4110, 4. H.R. 176, 5. H.R. 1461, 6. H.R. 5503; Predatory Lending Consumer Protection Act - 1. H.R. 3901, 2. H.R. 4213, 3. H.R. 4250, 4. S. 2415, 5. H.R. 1051, 6. H.R. 3607, 7. S. 2438, 8. H.R. 4818, 9. H.R. 833, 10. H.R. 1663, 11. H.R. 1865, 12. H.R. 1182, 13. H.R. 1295, 14. H.R. 2201, 15. H.R. 4471; Financial Services Regulatory Relief Act - 1. H.R. 665, 2. S. 900, 3. H.R. 3951, 4. H.R. 1375, 5. H.R. 3505, 6. S. 2856. 
Table 3. Passage of Bills

\begin{tabular}{|c|c|c|c|c|c|c|c|}
\hline \multirow{3}{*}{ Tight bill? } & \multicolumn{3}{|c|}{ Individual Bills } & \multirow{3}{*}{ Tight bill? } & \multicolumn{3}{|c|}{ Bills Categorized } \\
\hline & \multicolumn{2}{|c|}{ Signed into law? } & \multirow[t]{2}{*}{$\begin{array}{c}\text { Total number } \\
\text { of bills }\end{array}$} & & \multicolumn{2}{|c|}{ Signed into law? } & \multirow[t]{2}{*}{$\begin{array}{l}\text { Total number } \\
\text { of categories }\end{array}$} \\
\hline & No & Yes & & & No & Yes & \\
\hline No & $84 \%$ & $16 \%$ & 32 & No & $40 \%$ & $60 \%$ & 5 \\
\hline Yes & $100 \%$ & $0 \%$ & 15 & Yes & $100 \%$ & $0 \%$ & 1 \\
\hline Total number of bills & 42 & 5 & 47 & Total number of categories & 3 & 3 & 6 \\
\hline
\end{tabular}

Notes: The table shows the proportion and number of bills that were ultimately signed into law between 2000 and 2006 ,

distinguishing between lax and tight bills. Bills are categorized as lax or tight based on the rules they would impose on the financial institutions. In the last three columns, we group the bills into six categories: Commodity Futures Modernization Act; Bankruptcy Abuse Prevention and Consumer Protection Act; American Dream Downpayment Act; FHA Multifamily Housing Mortgage Loan Limit Adjustment Act; Predatory Lending Consumer Protection Act; Financial Services Regulatory Relief Act. 
Table 4. Summary Statistics

\begin{tabular}{|c|c|c|c|c|c|}
\hline Variable & Obs & Mean & Std. Dev. & Min & Max \\
\hline Number of bills & 47 & & & & \\
\hline Number of legislators & 790 & & & & \\
\hline Number of lobbyists & 575 & & & & \\
\hline Dummy $=1$ if switch to being in favor of deregulation & 32390 & 0.06 & 0.24 & 0 & 1 \\
\hline Dummy $=1$ if stance in favor of deregulation & 32390 & 0.39 & 0.49 & 0 & 1 \\
\hline Dummy $=1$ if roll call vote in favor of deregulation & 3006 & 0.69 & 0.46 & 0 & 1 \\
\hline Lobbying expenditures (in US\$) & 32390 & $3,896,924$ & $3,788,612$ & 262,374 & $14,700,000$ \\
\hline Lobbying expenditures (in log) & 32390 & 14.70 & 1.03 & 12.48 & 16.51 \\
\hline PAC contributions (in US\$) & 32390 & 2,341 & 5,983 & 1 & 83,861 \\
\hline PAC contributions (in log) & 32390 & 2.96 & 3.98 & 0.00 & 11.34 \\
\hline Lobbying expenditures by consumer organizations (in US\$) & 32390 & 22,149 & 67,172 & 1 & 287,260 \\
\hline Lobbying expenditures by consumer organizations (in log) & 32390 & 3.04 & 4.47 & 0.00 & 12.57 \\
\hline Ideology score & 31406 & 0.08 & -0.47 & 0.76 & 1.09 \\
\hline Republican & 32226 & 0.52 & 0.50 & 0 & 1 \\
\hline Worked in Wall Street & 32390 & 0.14 & 0.35 & 0 & 1 \\
\hline Worked in Wall Street after Congress & 32390 & 0.05 & 0.21 & 0 & 1 \\
\hline Connection between lobbyist and legislator & 32390 & 0.33 & 0.47 & 0 & 1 \\
\hline Connection through legislator's office & 32390 & 0.33 & 0.47 & 0 & 1 \\
\hline Connection through committee & 32390 & 0.07 & 0.25 & 0 & 1 \\
\hline Connected lobbyists & 32390 & 0.90 & 2.09 & 0 & 24 \\
\hline
\end{tabular}

Notes: All bills are classified as lax or tight based on the rules they would impose on the financial institutions (see Table A2 for more details). The bills are further grouped into six categories based on their similarities to reflect the fact that the bills that end up in the same 'category' actually are 'reincarnation' of each other (see Table 2 for the individual bill and category names). Note that each category and reincarnation pair defines an individual bill. The dummy for 'switch to being in favor of deregulation' takes on the value 1 if the legislator changed her vote from 'nay' ('aye') to 'aye' ('nay') on successive reincarnations of a lax (tight) bill, if the bill was ultimately voted on, and if the legislator switched from not (co-)sponsoring a bill to (co-)sponsoring, if the bill did not have a roll call. The dummy for 'stance in favor of deregulation' takes on the value 1 if the legislator voted 'aye' ('nay') on a lax (tight) bill, if the bill was ultimately voted on, and if the legislator sponsored or consponsored a bill, if the bill did not have a roll call. Lobbying expenditures are the total amount spent on lobbying on a particular bill by the financial firms that list the bill in their reports ('the affected firms'). Lobbying expenditures at the firm level for each specific bill is calculated by splitting the expenditure of that firm equally among all bills the firm lobbied on. Lobbying expenditures by consumer organizations are calculated in a similar manner. PAC contributions are the total amount given to a particular legislator's PACs by the affected firms, split across bills using the lobbying expenditure by a particular firm on that bill as weights. The 'Ideology score' is DW-nominate, calculated by Poole and Rosenthal (2007). Higher values of this variable corresponds to a more conservative political line. Republican is a dummy that equals 1 for legislators in the GOP, 0 for Democrats, and is set to missing for independents. Network connections are measured using the employment histories of both the legislators and the lobbyists. The variable 'Worked in Wall Street (after Congress)' is a dummy that equals 1 if the legislator has ever worked for a finance, insurance, or real estate firm (after s/he left public office). The variable 'Connection between lobbyist and legislator' is a dummy that equals 1 if a lobbyist working on a specific bill is connected to a particular legislator. This connection is defined either by the lobbyist having worked in that legislator's office ('Connection through legislator's office') or by the lobbyist having worked in a committee in which that legislator had a seat ('Connection through committee'). The variable 'Connected lobbyists' shows the number of lobbyists working on a specific bill that is connected to a particular legislator. 
Table 5. Lobbying, Connections, and Probability of Switch to Being in Favor of Deregulation

Dependent variable: Dummy $=1$ if stance changes from against to in favor of deregulation

\begin{tabular}{|c|c|c|c|c|}
\hline & $\begin{array}{c}\text { I } \\
\text { Full sample } \\
\end{array}$ & $\begin{array}{c}\text { II } \\
\text { Full sample } \\
\end{array}$ & $\begin{array}{c}\text { III } \\
\text { Unconnected } \\
\text { lobbyists } \\
\end{array}$ & $\begin{array}{c}\text { IV } \\
\text { Connected } \\
\text { lobbyists } \\
\end{array}$ \\
\hline Lobbying expenditures & $\begin{array}{c}0.370 * * * \\
{[0.016]}\end{array}$ & & $\begin{array}{c}0.262 * * * \\
{[0.023]}\end{array}$ & $\begin{array}{c}0.464 * * * \\
{[0.061]}\end{array}$ \\
\hline $\begin{array}{l}\text { Connection between lobbyist and } \\
\text { legislator }\end{array}$ & & $\begin{array}{c}0.025 * * * \\
{[0.004]}\end{array}$ & & \\
\hline Observations & 32390 & 32390 & 21662 & 10728 \\
\hline R-squared & 0.48 & 0.46 & 0.45 & 0.62 \\
\hline Legislator * Congress fixed effects & yes & yes & yes & yes \\
\hline Category $*$ Congress fixed effects & yes & yes & yes & yes \\
\hline Reincarnation * Congress fixed effects & yes & yes & yes & yes \\
\hline
\end{tabular}

Notes: All regressions are estimated as linear probability models. All bills are classified as lax or tight based on the rules they would impose on the financial institutions (see Table A2 for more details). The bills are further grouped into six categories based on their similarities to reflect the fact that the bills that end up in the same 'category' actually are 'reincarnation' of each other (see Table 2 for the individual bill and category names). Note that each category and reincarnation pair defines an individual bill. The dependent variable is a dummy with value 1 if the legislator changed her vote from 'nay' ('aye') to 'aye' ('nay') on successive reincarnations of a lax (tight) bill, if the bill was ultimately voted on, and if the legislator switched from not (co-)sponsoring a bill to (co)sponsoring, if the bill did not have a roll call. Lobbying expenditures are the total amount spent on lobbying on a particular bill by the financial firms that list the bill in their reports ('the affected firms'), expressed in natural logs. Lobbying expenditures at the firm level for each specific bill is calculated by splitting the expenditure of that firm equally among all bills the firm lobbied on. 'Connection between lobbyist and legislator' is a dummy that equals 1 if a lobbyist working on a specific bill is connected to a particular legislator. This connection is defined either by the lobbyist having worked in that legislator's office or by the lobbyist having worked in a committee in which that legislator had a seat. In columns I and II, the regression is estimated on the full sample. In column III, the regression is estimated using only the observations where the legislator and the lobbyists are not connected. In column IV, the regression is estimated using only the observations where the legislator and the lobbyists are connected. All regressions include 'Bill complexity', defined as the total number of pages that describe and contain the full text of a bill, expressed in logs, and a dummy that is 1 if the bill is classified as tight. Robust standard errors clustered at the legislator level are in parentheses. ${ }^{* *}, * *$ and $*$ denote significance at 1,5 and 10 percent levels, respectively. 
Table 6. Probability of Switch and Legislator Characteristics

\begin{tabular}{|c|c|c|c|c|c|c|}
\hline \multicolumn{7}{|c|}{ Dependent variable: Dummy $=1$ if stance changes from against to in favor of deregulation } \\
\hline & I & II & III & IV & $\mathrm{V}$ & VI \\
\hline Lobbying expenditures & $\begin{array}{c}0.381 * * * \\
{[0.016]}\end{array}$ & $\begin{array}{c}0.363 * * * \\
{[0.016]}\end{array}$ & & & $\begin{array}{c}0.367 * * * \\
{[0.016]}\end{array}$ & $\begin{array}{c}0.370 * * * \\
{[0.016]}\end{array}$ \\
\hline $\begin{array}{l}\text { Lobbying expenditures * Ideology } \\
\text { score }\end{array}$ & $\begin{array}{c}0.016^{* * *} \\
{[0.005]}\end{array}$ & & & & & \\
\hline Lobbying expenditures * Republican & & $\begin{array}{c}0.016^{* * *} \\
{[0.005]}\end{array}$ & & & & \\
\hline $\begin{array}{l}\text { Connection between lobbyist and } \\
\text { legislator }\end{array}$ & & & $\begin{array}{c}0.024 * * * \\
{[0.005]}\end{array}$ & $\begin{array}{c}0.024 * * * \\
{[0.006]}\end{array}$ & & \\
\hline $\begin{array}{l}\text { Connection between lobbyist and } \\
\text { legislator * Ideology score }\end{array}$ & & & $\begin{array}{c}0.000 \\
{[0.009]}\end{array}$ & & & \\
\hline $\begin{array}{l}\text { Connection between lobbyist and } \\
\text { legislator * Republican }\end{array}$ & & & & $\begin{array}{c}0.001 \\
{[0.009]}\end{array}$ & & \\
\hline $\begin{array}{l}\text { Lobbying expenditures * Worked in } \\
\text { Wall Street }\end{array}$ & & & & & $\begin{array}{c}0.021 * * * \\
{[0.007]}\end{array}$ & \\
\hline $\begin{array}{l}\text { Lobbying expenditures * Worked in } \\
\text { Wall Street after Congress }\end{array}$ & & & & & & $\begin{array}{l}-0.002 \\
{[0.012]}\end{array}$ \\
\hline Observations & 31406 & 32226 & 31406 & 32226 & 32390 & 32390 \\
\hline R-squared & 0.49 & 0.48 & 0.46 & 0.46 & 0.48 & 0.48 \\
\hline Legislator * Congress fixed effects & yes & yes & yes & yes & yes & yes \\
\hline Category * Congress fixed effects & yes & yes & yes & yes & yes & yes \\
\hline Reincarnation * Congress fixed effects & yes & yes & yes & yes & yes & yes \\
\hline
\end{tabular}

Notes: All regressions are estimated as linear probability models. All bills are classified as lax or tight based on the rules they would impose on the financial institutions (see Table A2 for more details). The bills are further grouped into six categories based on their similarities to reflect the fact that the bills that end up in the same 'category' actually are 'reincarnation' of each other (see Table 2 for the individual bill and category names). Note that each category and reincarnation pair defines an individual bill. The dependent variable is a dummy with value 1 if the legislator changed her vote from 'nay' ('aye') to 'aye' ('nay') on successive reincarnations of a lax (tight) bill, if the bill was ultimately voted on, and if the legislator switched from not (co-)sponsoring a bill to (co-)sponsoring, if the bill did not have a roll call. Lobbying expenditures are the total amount spent on lobbying on a particular bill by the financial firms that list the bill in their reports ('the affected firms'), expressed in natural logs. Lobbying expenditures at the firm level for each specific bill is calculated by splitting the expenditure of that firm equally among all bills the firm lobbied on. 'Connection between lobbyist and legislator' is a dummy that equals 1 if a lobbyist working on a specific bill is connected to a particular legislator. This connection is defined either by the lobbyist having worked in that legislator's office or by the lobbyist having worked in a committee in which that legislator had a seat. The 'Ideology score' is DW-nominate, calculated by Poole and Rosenthal (2007). Higher values of this variable corresponds to a more conservative political line. 'Republican' is a dummy that equals 1 for legislators that are a member of the GOP, 0 for members of the Democratic Party, and is set to missing for independents. 'Worked in Wall Street' is a dummy that equals 1 if the legislator has ever worked for a finance, insurance, or real estate firm. All regressions include 'Bill complexity', defined as the total number of pages that describe and contain the full text of a bill, expressed in logs, and a dummy that is 1 if the bill is classified as tight. Robust standard errors clustered at the legislator level are in parentheses. ${ }^{* * *}, * *$ and $*$ denote significance at 1,5 and 10 percent levels, respectively. 
Table 7. Probability of Switch and PAC Contributions

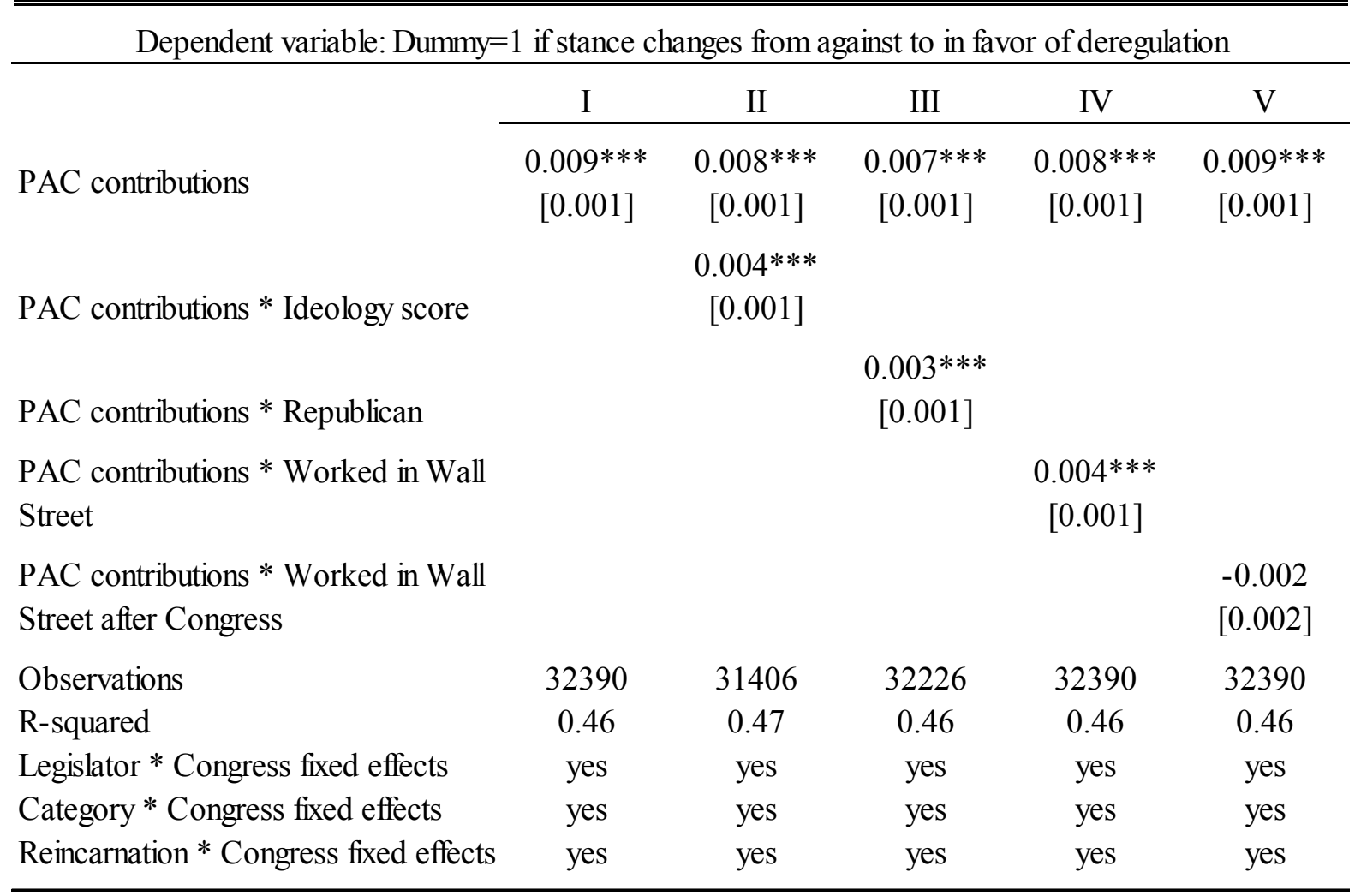

Notes: All regressions are estimated as linear probability models. All bills are classified as lax or tight based on the rules they would impose on the financial institutions (see Table A2 for more details). The bills are further grouped into six categories based on their similarities to reflect the fact that the bills that end up in the same 'category' actually are 'reincarnation' of each other (see Table 2 for the individual bill and category names). Note that each category and reincarnation pair defines an individual bill. The dependent variable is a dummy with value 1 if the legislator changed her vote from 'nay' ('aye') to 'aye' ('nay') on successive reincarnations of a lax (tight) bill, if the bill was ultimately voted on, and if the legislator switched from not (co-)sponsoring a bill to (co-)sponsoring, if the bill did not have a roll call. PAC contributions, expressed in logs, are the total amount given to a particular legislator's PACs by the affected firms, as determined by whether the firm named the bill in its lobbying report and split across bills using the lobbying expenditure by a particular firm on that bill as weights. 'Connection between lobbyist and legislator' is a dummy that equals 1 if a lobbyist working on a specific bill is connected to a particular legislator. This connection is defined either by the lobbyist having worked in that legislator's office or by the lobbyist having worked in a committee in which that legislator had a seat. The 'Ideology score' is DW-nominate, calculated by Poole and Rosenthal (2007). Higher values of this variable corresponds to a more conservative political line. 'Republican' is a dummy that equals 1 for legislators that are a member of the GOP, 0 for members of the Democratic Party, and is set to missing for independents. 'Worked in Wall Street' is a dummy that equals 1 if the legislator has ever worked for a finance, insurance, or real estate firm. All regressions include 'Bill complexity', defined as the total number of pages that describe and contain the full text of a bill, expressed in logs, and a dummy that is 1 if the bill is classified as tight. Robust standard errors clustered at the legislator level are in parentheses. $* * * * *$ and $*$ denote significance at 1,5 and 10 percent levels, respectively. 
Table 8. Hiring of Lobbyists on Reincarnations of Bills

(in percent of total number of lobbyists working on the bill)

\begin{tabular}{|c|c|c|c|c|c|c|}
\hline Reincarnation $\downarrow \backslash$ Category $\longrightarrow$ & $\begin{array}{c}\text { Commodity Futures } \\
\text { Modernization Act }\end{array}$ & $\begin{array}{l}\text { Bankruptcy Abuse } \\
\text { Prevention and } \\
\text { Consumer Protection } \\
\text { Act }\end{array}$ & $\begin{array}{c}\text { American Dream } \\
\text { Downpayment Act }\end{array}$ & $\begin{array}{c}\text { FHA Multifamily } \\
\text { Housing Mortgage } \\
\text { Loan Limit } \\
\text { Adjustment Act } \\
\end{array}$ & $\begin{array}{c}\text { Predatory Lending } \\
\text { Consumer Protection } \\
\text { Act }\end{array}$ & $\begin{array}{c}\text { Financial Services } \\
\text { Regulatory Relief Act }\end{array}$ \\
\hline 1 & n.a. & n.a. & n.a. & n.a. & n.a. & n.a. \\
\hline 2 & 97 & 85 & 96 & 99 & 99 & 61 \\
\hline 3 & 97 & 99 & 91 & 98 & 98 & 62 \\
\hline 4 & & 91 & 97 & 99 & 99 & 77 \\
\hline 5 & & 79 & 92 & 85 & 93 & 70 \\
\hline 6 & & 92 & 100 & 85 & 94 & 92 \\
\hline 7 & & 88 & 98 & & 96 & \\
\hline 8 & & & 96 & & 98 & \\
\hline 9 & & & 99 & & 57 & \\
\hline 10 & & & 95 & & 58 & \\
\hline 11 & & & & & 95 & \\
\hline 12 & & & & & 94 & \\
\hline 13 & & & & & 94 & \\
\hline 14 & & & & & 85 & \\
\hline 15 & & & & & 95 & \\
\hline
\end{tabular}

Notes: The table reports the percent of lobbyists who worked on successive reincarnations (i.e., worked on nth and (n-1)th reincarnations) within the same category. The bills are grouped into six categories based on their similarities in their titles, descriptions, and provisions. Each attempt to pass a bill in a given category is labeled as a 'reincarnation'. The names of the bills brought forward in various attempts under the same broad concept are as follows: Commodity Futures Modernization Act - 1. H.R. 4541; 2. S. 2697; 3. H.R. 5660; Bankruptcy Abuse Prevention and Consumer Protection Act - 1. H.R. 975; 2. H.R. 1529; 3. H.R. 1860; 4. S. 1920; 5. S. 256; 6. H.R. 685; 7. H.R. 2060; American Dream Downpayment Act - 1. H.R. 1776; 2. H.R. 5640; 3. H.R. 3206; 4. S. 1620; 5. H.R.1276; 6. S.811; 7. H.R. 3755; 8. H.R. 5121; 9. S. 3535; 10. S. 2169; FHA Multifamily Housing Mortgage Loan Limit Adjustment Act - 1. H.R. 1629; 2. S. 1163; 3. H.R. 4110; 4. H.R. 176; 5. H.R. 1461; 6. H.R. 5503; Predatory Lending Consumer Protection Act - 1. H.R. 3901; 2. H.R. 4213; 3. H.R. 4250; 4. S. 2415; 5. H.R. 1051; 6. H.R. 3607; 7. H.R. 3807; 8. S. 2438; 9. H.R. 4818; 10. H.R. 833; 11. H.R. 1663; 12. H.R. 1865; 13. H.R. 1182; 14. H.R. 1295; 15. H.R. 2201; 16. H.R. 4471; 17. H.R. 3915; Financial Services Regulatory Relief Act - 1. H.R. 665; 2. S. 900; 3. H.R. 3951; 4. H.R. 1375; 5. H.R. 3505; 6. S. 2856. 
Table 9. Lobbying, Connections, and Probability of Switch to Being in Favor of Deregulation: Robustness to Additional Controls

\begin{tabular}{|c|c|c|c|c|c|c|c|c|c|c|}
\hline & I & II & III & IV & $\mathrm{V}$ & VI & VII & VIII & IX & $\mathrm{X}$ \\
\hline Lobbying expenditures & $\begin{array}{c}0.290^{* * *} \\
{[0.013]}\end{array}$ & & $\begin{array}{c}0.210^{* * *} \\
{[0.014]}\end{array}$ & & $\begin{array}{c}0.133^{* * *} \\
{[0.009]}\end{array}$ & & & $\begin{array}{c}0.370^{* * *} \\
{[0.016]}\end{array}$ & $\begin{array}{c}0.370^{* * *} \\
{[0.015]}\end{array}$ & \\
\hline $\begin{array}{l}\text { Connection between lobbyist and } \\
\text { legislator }\end{array}$ & & $\begin{array}{c}0.021 * * * \\
{[0.004]}\end{array}$ & & $\begin{array}{c}0.013 * * * \\
{[0.004]}\end{array}$ & & $\begin{array}{c}0.020^{* * *} \\
{[0.004]}\end{array}$ & & & & $\begin{array}{r}0.026^{* * *} \\
{[0.004]}\end{array}$ \\
\hline Voting history & $\begin{array}{c}0.199 * * * \\
{[0.005]}\end{array}$ & $\begin{array}{c}0.222 * * * \\
{[0.005]}\end{array}$ & & & & & & & & \\
\hline Switch along party lines & & & $\begin{array}{c}0.059 * * * \\
{[0.002]}\end{array}$ & $\begin{array}{c}0.073 * * * \\
{[0.003]}\end{array}$ & & & & & & \\
\hline Additional amendments & & & & & $\begin{array}{c}0.002^{* * *} \\
{[0.000]}\end{array}$ & $\begin{array}{c}0.002 * * * \\
{[0.000]}\end{array}$ & & & & \\
\hline $\begin{array}{l}\text { Dummy }=1 \text { if lobbying expenditures by } \\
\text { consumer organizations }>0\end{array}$ & & & & & & & $\begin{array}{c}0.419 * * * \\
{[0.027]}\end{array}$ & $\begin{array}{c}0.211^{* * *} \\
{[0.009]}\end{array}$ & & \\
\hline Observations & 32390 & 32390 & 32390 & 32390 & 32390 & 32390 & 32390 & 32390 & 32390 & 32390 \\
\hline R-squared & 0.50 & 0.49 & 0.49 & 0.49 & 0.48 & 0.47 & 0.45 & 0.48 & 0.42 & 0.40 \\
\hline Legislator * Congress fixed effects & yes & yes & yes & yes & yes & yes & yes & yes & no & no \\
\hline Category* Congress fixed effects & yes & yes & yes & yes & yes & yes & yes & yes & yes & yes \\
\hline Reincarnation $*$ Congress fixed effects & yes & yes & yes & yes & yes & yes & yes & yes & yes & yes \\
\hline
\end{tabular}

Notes: All regressions are estimated as linear probability models. All bills are classified as lax or tight based on the rules they would impose on the financial institutions (see Table A2 for more details). The bills are further grouped into six categories based on their similarities to reflect the fact that the bills that end up in the same 'category' actually are 'reincarnation' of each other (see Table 2 for the individual bill and category names). Note that each category and reincarnation pair defines an individual bill. The dependent variable is a dummy with value 1 if the legislator changed her vote from 'nay' ('aye') to 'aye' ('nay') on successive reincarnations of a lax (tight) bill, if the bill was ultimately voted on, and if the legislator switched from not (co-)sponsoring a bill to (co-)sponsoring, if the bill did not have a roll call. Lobbying expenditures are the total amount spent on lobbying on a particular bill by the financial firms that list the bill in their reports ('the affected firms'), expressed in natural logs. Lobbying expenditures at the firm level for each specific bill is calculated by splitting the expenditure of that firm equally among all bills the firm lobbied on. 'Connection between lobbyist and legislator' is a dummy that equals 1 if a lobbyist working on a specific bill is connected to a particular legislator. This connection is defined either by the lobbyist having worked in that legislator's office or by the lobbyist having worked in a committee in which that legislator had a seat. In columns I and II, voting history is proxied by a dummy equal to 1 if the legislator expressed a stance against deregulation in the last three reincarnations of a particular bill. In columns III and IV, the regressions control for switch along the party lines, measured by the number of legislators in the same party as the legislator who switch. In columns V and VI, the regressions control for the number of new amendments to the previous reincarnation of the bill. In columns VII and VIII, lobbying expenditures by consumer organizations are defined in a similar manner and then a dummy that equals 1 if these expenditures are positive is constructed. In columns IX and X, we add a time trend. However, due to collinearity, we drop the legislator*congress interactions, and include only the legislator fixed effects. All regressions (except Columns V and VI) include 'Bill complexity', defined as the total number of pages that describe and contain the full text of a bill, expressed in logs, and a dummy that is 1 if the bill is classified as tight. Robust standard errors clustered at the legislator level are in parentheses. $* * *, * *$ and $*$ denote significance at 1,5 and 10 percent levels, respectively. 
Table 10. Robustness: Alternative Measures of Legislator's Stance

\begin{tabular}{|c|c|c|c|c|c|c|c|c|c|c|c|}
\hline & $\mathrm{I}$ & II & III & IV & $\mathrm{V}$ & VI & VII & VIII & IX & $\mathrm{X}$ & $\mathrm{XI}$ \\
\hline Lobbying expenditures & $\begin{array}{c}0.311 * * * \\
{[0.013]}\end{array}$ & & $\begin{array}{c}0.282 * * * \\
{[0.020]}\end{array}$ & & $\begin{array}{c}-0.254 * * * \\
{[0.016]}\end{array}$ & & $\begin{array}{c}0.625 * * * \\
{[0.026]}\end{array}$ & & $\begin{array}{c}0.100 * * * \\
{[0.004]}\end{array}$ & & $\begin{array}{c}0.335 * * * \\
{[0.121]}\end{array}$ \\
\hline $\begin{array}{l}\text { Connection between lobbyist and } \\
\text { legislator }\end{array}$ & & $\begin{array}{c}0.021 * * * \\
{[0.005]}\end{array}$ & & $\begin{array}{c}0.011 \\
{[0.009]}\end{array}$ & & $\begin{array}{c}0.003 \\
{[0.004]}\end{array}$ & & $\begin{array}{c}0.022 * * * \\
{[0.006]}\end{array}$ & & $\begin{array}{c}0.031 * * * \\
{[0.004]}\end{array}$ & \\
\hline Observations & 29938 & 29938 & 19126 & 19126 & 32390 & 32390 & 32390 & 32390 & 37130 & 37130 & 733 \\
\hline R-squared & 0.49 & 0.48 & 0.64 & 0.64 & 0.46 & 0.45 & 0.43 & 0.41 & 0.82 & 0.82 & 0.55 \\
\hline Legislator * Congress fixed effects & yes & yes & yes & yes & yes & yes & yes & yes & yes & yes & yes \\
\hline Category $*$ Congress fixed effects & yes & yes & yes & yes & yes & yes & yes & yes & yes & yes & no \\
\hline Reincarnation $*$ Congress fixed effects & yes & yes & yes & yes & yes & yes & yes & yes & yes & yes & no \\
\hline
\end{tabular}

Notes: All regressions are estimated as linear probability models. All bills are classified as lax or tight based on the rules they would impose on the financial institutions (see Table A2 for more details). The bills are further grouped into six categories based on their similarities to reflect the fact that the bills that end up in the same 'category' actually are 'reincarnation' of each other (see Table 2 for the individual bill and category names). Note that each category and reincarnation pair defines an individual bill. Recall that the dependent variable in the baseline regressions in Tables 5-8 is a dummy with value 1 if the legislator changed her vote from 'nay' ('aye') to 'aye' ('nay') on successive reincarnations of a lax (tight) bill, if the bill was ultimately voted on, and if the legislator switched from not (co-)sponsoring a bill to (co-)sponsoring, if the bill did not have a roll call. All other cases (i.e., when no switch happened and when the switch was from being in favor to being against) are encoded as 0 . The dependent variable in columns I-II is the same as the baseline switch measure, but replaces the cases of 0 with missing if the switch was from being in favor to being against. The dependent variable in columns III-IV is the same as the baseline switch measure, but replaces the cases of 0 with missing if the stance on the previous attempt of the same bill was in favor of deregulation. The dependent variable in columns V-VI is the mirror image of this original switch measure, i.e., a dummy with value 1 if the legislator changed her vote from 'aye' ('nay') to 'nay' ('aye') on successive reincarnations of a lax (tight) bill, if the bill was ultimately voted on, and if the legislator switched from (co-)sponsoring a bill to not (co-)sponsoring, if the bill did not have a roll call. All other cases (i.e., when no switch happened and when the switch was from being against to being in favor) are encoded as 0 . The dependent variable in columns VII-VIII takes on three values: $-1,0$, and +1 for switch in stance from being in favor to being against deregulation, keeping the stance unchanged, and for switch in stance from being against to being in favor of deregulation, respectively. The dependent variable in columns IX-X is a dummy for the legislator's position being in favor of deregulation (rather than the switch in the position as in all other specifications). Finally, the dependent variable in column XI is the switch in stance from being against to being in favor based on only those bills which have recorded roll call data. Given the limited number of observations, regression XI can be implemented with only a restricted set of fixed effects and there is not enough variation to estimate the coefficient on connections. Lobbying expenditures are the total amount spent on lobbying on a particular bill by the financial firms that list the bill in their reports ('the affected firms'), expressed in natural logs. Lobbying expenditures at the firm level for each specific bill is calculated by splitting the expenditure of that firm equally among all bills the firm lobbied on. All regressions include 'Bill complexity', defined as the total number of pages that describe and contain the full text of a bill, expressed in logs, and a dummy that is 1 if the bill is classified as tight. Robust standard errors clustered at the legislator level are in parentheses. ***,** and * denote significance at 1,5 and 10 percent levels, respectively. 
Table 11. Robustness: Alternative Measures of Lobbying

Dependent variable: Dummy=1 if stance changes from against to in favor of deregulation

\begin{tabular}{|c|c|c|c|}
\hline & $\mathrm{I}$ & II & III \\
\hline Lobbying expenditures & $\begin{array}{c}0.319 * * * \\
{[0.013]}\end{array}$ & $\begin{array}{c}0.153 * * * \\
{[0.006]}\end{array}$ & $\begin{array}{c}0.147 * * * \\
{[0.006]}\end{array}$ \\
\hline Observations & 32390 & 32390 & 32390 \\
\hline R-squared & 0.47 & 0.47 & 0.46 \\
\hline Legislator * Congress fixed effects & yes & yes & yes \\
\hline Category $*$ Congress fixed effects & yes & yes & yes \\
\hline Reincarnation $*$ Congress fixed effects & yes & yes & yes \\
\hline
\end{tabular}

Notes: All regressions are estimated as linear probability models. All bills are classified as lax or tight based on the rules they would impose on the financial institutions (see Table A2 for more details). The bills are further grouped into six categories based on their similarities to reflect the fact that the bills that end up in the same 'category' actually are 'reincarnation' of each other (see Table 2 for the individual bill and category names). Note that each category and reincarnation pair defines an individual bill. The dependent variable is a dummy with value 1 if the legislator changed her vote from 'nay' ('aye') to 'aye' ('nay') on successive reincarnations of a lax (tight) bill, if the bill was ultimately voted on, and if the legislator switched from not (co-)sponsoring a bill to (co-)sponsoring, if the bill did not have a roll call. Lobbying expenditures are the total amount spent on lobbying on a particular bill by the financial firms that list the bill in their reports ('the affected firms'), expressed in natural logs. Lobbying expenditures at the firm level for each specific bill is calculated by splitting the expenditure of that firm equally among all bills the firm lobbied on. In all regressions, lobbying expenditures are aggregate expenditures by all firms that lobby on a bill but the firm-level expenditures are calculated in three alternative ways. Lobbying expenditures in column I corresponds to the measure in Table 5, but also includes lobbying by bankers' and other industry associations. Lobbying expenditures in column II are overall lobbying expenditures (on all issues rather than only the specific issues of interest) by the firm. Lobbying expenditures in column III uses the share of reports that list that issue to split the firm-level lobbying expenditures among different issues. All regressions include 'Bill complexity', defined as the total number of pages that describe and contain the full text of a bill, expressed in logs, and a dummy that is 1 if the bill is classified as tight. Robust standard errors clustered at the legislator level are in parentheses. $* * *, * *$ and $*$ denote significance at 1,5 and 10 percent levels, respectively. 